\title{
The Political Economy of Innovation Why is Brazil Stuck in the Technology Ladder?1,2
}

\author{
Tulio Chiarini ${ }^{1}$ \\ https://orcid.org/0000-0002-3758-8413 \\ Fernanda Cimini ${ }^{2}$ \\ http://orcid.org/0000-0003-2170-6443 \\ Marcia Siqueira Rapini2 \\ https://orcid.org/0000-0002-8035-3003 \\ Leandro Alves Silva ${ }^{2}$ \\ https://orcid.org/0000-0002-4017-1045 \\ ${ }^{1}$ Instituto Nacional de Tecnologia, Rio de Janeiro/RJ, Brazil \\ 2Universidade Federal de Minas Gerais, Belo Horizonte/MG, Brazil
}

The essay considers the role of big private businesses (BBs) within the Brazilian national system of innovation (NSI). Our question is as follows: How do the innovation practices and political behavior adopted by BBs shape the Brazilian NSI? It is our claim that although BBs play a prominent role in leading innovation nationally, they are not supportive of institution-intensive solutions for strengthening the NSI, and thereby contribute to the creation of a dynamic that we call the 'low-innovation trap'. The obstacles to escaping this trap are manifold, but here we shall focus on 01 . the lack of coordination between actors and instruments within government, 02. the high level of instability in the Science, Technology and Innovation (ST\&I) budget, 03. the increasing obstacles faced by BBs wishing to innovate and 04. the lack of correspondence between government proposals and societal demands. Without a strong coalition pushing for it to be upgraded, it is likely that the NSI will remain unfit for purpose.

Keywords: National system of innovation; less-developed countries; lowinnovation trap; big business; Brazil.

http://doi.org/ 10.1590/1981-3821202000020001

For data replication, see: https://doi.org/10.7910/DVN/WIAEL2

Correspondence: Tulio Chiarini. E-mail: tulio.chiarini@int.gov.br

This publication is registered under a CC-BY Licence.

${ }^{1}$ JEL codes: 030; 038; P16; F23.

${ }^{2}$ Acknowledgements: Opinions expressed herein are those of only the authors. They do not necessarily reflect the views of, or involve any responsibility for, the institutions to which they are affiliated. We would like to thank the anonymous reviewers and the Editor-in-Chief of this journal for their valuable comments. Very early discussions on the concept of the 'low-innovation trap' in Brazil were presented in Athens at the 15th Globelics International Conference, 2017, under the name "Domestic businesses, Multinationals and the State: an essay on the dynamics underpinning the 'low-innovation trap' in Brazil", and in Mexico City at the Lalics Conference, 2018, under the name "The dynamics underpinning the 'low-innovation trap' in Latin America: the case of Brazil". 
A large and growing body of literature argues that building a strong National System of Innovation (hereinafter NSI) is a precondition to climbing the technological ladder and thereby overcoming underdevelopment (FREEMAN, 1995, 1987). In this literature the term 'NSI' refers to broad interactions between institutions including governments, firms and Science, Technology and Innovation (hereinafter ST\&I) actors, such as universities and research institutes (LUNDVALL, 2007, 1992). Based on an evolutionary economic approach (DOSI et al., 1988; NELSON and WINTER, 1982), the literature suggests that during the catching-up process it is to be expected that a certain amount of temporal mismatch between universities, research institutes and the productive sector may occur as a consequence of the cutting-edge knowledge produced and adopted by ST\&I actors (ALBUQUERQUE et al., 2015). This temporal mismatch may or may not be converted into technological opportunities by existing and new businesses (PÉREZ, 2001) depending on the institutional framework available (CHAMINADE and EDQUIST, 2010; EDQUIST, 1997).

In mature NSIs (ALBUQUERQUE, 1999), technological mismatches push the productive sector to adjust to new technologies, leading to new equilibriums at higher technological levels. Over time, this dynamic is eventually repeated in a nonlinear fashion by creating opportunities for new entrepreneurs (SCHUMPETER, 2017), challenging existing industries and advancing the development process. In contrast to mature NSIs, relatively less dynamic systems lack strong major institutional actors, especially top-level universities, and a set of vigorous interactions between firms, research institutes and universities that could coordinate the innovation process at the production level (AROCENA, GÖRANSSON and SUTZ, 2015). Consequently, mismatches do not take place as expected: universities and research institutes do not perform well in ST\&I and when they do work properly the productive sector does not take full advantage of the opportunities to innovate (AROCENA and SUTZ, 2005; SRINIVAS and SUTZ, 2008).

In the footsteps of scholars advocating the need for a 'southern' or 'peripheral' perspective on NSIs (ALBUQUERQUE et al., 2015; AROCENA and SUTZ, 2010), we aim in this article to understand the conditions that trap less-developed countries in a situation of continuous mismatch between ST\&I actors and businesses. Specifically, we focus on institutional fragilities that may inhibit the 
translation of ST\&I efforts into the productive sector, thus blocking co-evolutionary processes. Our claim is that because the co-evolutionary process of mismatches between ST\&I actors and firms may generate conflicts and pressures for structural and institutional changes, strengthening the NSI requires the support of a strong coalition that embraces the uncertain pace of technological change. For this reason, the answer to the question regarding the opportunities for climbing the technological ladder must, in our view, consider the political sphere.

Countries that were able to escape from the trap and climb up the technological ladder managed to reduce the impediments to collective action faced by ST\&I and business actors by planning and gathering the resources needed to build and refine their NSIs. Existing NSI scholarship has emphasized the role played by the State in driving innovation. Japan (FREEMAN, 1987; ODAGIRI, 2006), South Korea (KIM, 1999; LEE, 2019; WESTPHAL, KIM, and DAHLMAN, 1985), Taiwan (AMSDEN, 2001; HOU and GEE, 1993) and Singapore (YEUNG, 2006) are commonly-cited examples. Moreover, seminal work has highlighted the importance of big businesses (BBs) in promoting innovation and economic upgrading (CHANDLER JR., 1990; PENROSE, 1959). These examples underline the importance of States encouraging the incubation of large national champions in search of innovative results (AMSDEN, 2001; LEE, 2019), and again Japan and South Korea spring to mind with their 'keiretsu and chaebol', respectively.

The historical trajectory of the Brazilian economy challenges arguments on the roles of the State and BBs in driving economic upgrading. Compared to its peers in Latin America and the Caribbean and other less-developed countries (LDCs), Brazil has managed to develop a considerable amount of State capabilities and has been able to strengthen private actors by means of supporting domestic BBs and attracting foreign direct investment (FDI) - not only during the heydays of the import substitution industrialization regime but also after liberalization (HIRATUKA, COUTINHO, and LAPLANE, 2003). During the 2000s, especially under the two Lula governments, there was a clear intent to push the productive sector through the promotion of national champions, the internationalization of domestic firms and the implementation of horizontal industrial policies (CARVALHO, 2018). Nonetheless, Brazilian companies have made scant progress in terms of technological innovation, and public funds injected into $R \& D$ activities have 
not been translated into commercial innovation (ZUÑIGA et al., 2016). The Brazilian and similar cases call for an examination of the complementarities between the State and BBs (domestic and MNCs) in fostering NSIs.

Because innovation is a long-term, complex and risky endeavor, businesses are sensitive to any disruption or shift in public policies. For this reason, the institutionalization and continuity of science, technology and innovation (ST\&I) policies over a long period of time would be an even more valuable contributor to the Brazilian NSI than, say, predictable injections of public funds. In fact, in less dynamic NSIs, massive public investments in $R \& D$ can produce undesirable results: firms feel compelled to focus on short-term projects in anticipation of policy changes and resources end up being captured by incumbents (BREZNITZ and ORNSTON, 2017). This vicious cycle is characteristic of the aforementioned 'low innovation trap', in which the existing economic structure inhibits the formation of upgrading coalitions that could sustain a long-term project for strengthening the NSI.

The first section of this paper constitutes this introduction; the remainder is organized as follows: the second section begins with a puzzle, examining the complementarities between BBs and the State that lead to the 'low-innovation trap'. The original research contribution made by this article resides in this section. Section three focuses on Government initiatives, although it is far from exhaustive given the full panoply of ST\&I instruments in Brazil. Section four focuses on the behavior of BBs, contrasting their innovation activities with political initiatives aimed at strengthening the Brazilian NSI. Finally, we conclude with the assertion that Brazil is trapped in a low-innovation dynamic which we believe is partly caused by fragilities in the coalition that supports innovation. The absence of a strong private coalition that could support comprehensive investments in the NSI make pro-innovation public policies extremely vulnerable.

\section{Setting up the debate: businesses, politics and the low-innovation trap}

Doner and Schneider $(2019,2016)$ recently set up the debate on upgrading coalitions by bringing business policies to the heart of the literature on the middleincome trap. Although the literature on economic upgrading has never neglected the 
role of politics in changing the economic structure, the focus has most often been on the State.

Thanks to the seminal work of Gerschenkron (1962), State initiatives are widely perceived as one of the most important mechanisms for economic upgrading. In fact, the importance of public incentives became even more widely appreciated after the publication of Mariana Mazzuccato's books on the subject $(2019,2013)$, which outlined the crucial role played by the U.S. Government in the development of some of today's most important technologies. However, the fact that States can build institutions does not mean that they have the capacities or the political will to do so (EVANS, 1980). As Gourevitch (1986) famously put it, 'policies require politics'.

Upgrading policies carry an aura of national cohesion with strong societal appeal; after all, who would oppose high quality education, technological autonomy and economic catch-up? Yet the politics of upgrading are far from smooth. From an evolutionary point of view, upgrading is not only redistributive but also destructive (SCHUMPETER, 1943). According to Nelson (2008):

Achieving the needed reforms in economic structure may well be a more difficult task than gaining the scientific and engineering knowledge needed to operate the new technologies. There are several reasons. One is the political power of old firms and industries, and the difficulties they may have in transforming themselves. For comfortable, politically well-connected old firms, creative destruction is not a welcome thing. Politically and socially, creative destruction is not easy to handle (NELSON, 2008, p. 17).

In this sense, lagging behind may not only be profitable, but also a survival strategy for those who hold economic power. This is the essence of the 'trap'. BBs might deliver better innovation results than other sized firms, which may serve as a justification for government investment in and incentives in favor of their activities. However, governments cannot count on them to support institution-intensive solutions that could enable a country to exit the trap.

Due to their advantages of scale and scope, BBs are expected to be leading agents of innovation because they tend to be more efficient in developing new technologies than smaller firms (COHEN, 2010; COHEN and KLEPPER, 1996; NELSON and WINTER, 1982). Consequently, BBs have become the primary targets 
of public incentives aimed at fostering innovation in less-developed countries. Both the Japanese and the South Korean experiences are used as successful empirical cases to criticize the 'small is beautiful' idea (SCHUMACHER, 1973) and to defend the concentration and centralization of the capital of nationally-owned businesses. According to such a point of view, this is the only way for national businesses to compete globally, as they enjoy economies of scale and scope (CHANDLER JR., 1990) that enable them to fight for disputable market share and can draw on resources sufficient to invest in R\&D (SCHUMPETER, 2003).

Notwithstanding the foregoing, the patterns of interaction between states and BBs are often fuzzy. The experience of East Asian big businesses contrasts with that in Latin America, where BBs are mostly concentrated in commodities, regulated sectors (especially banking and utilities), natural oligopolies (such as cement and beer) and low-technology manufacturing (DONER and SCHNEIDER, 2016). The contrasting roles of BBs in East Asia and Latin America cannot be understood without looking at the development paths followed by the two regions.

While East Asia has chosen a nationalist path and sought to lay the foundations for indigenous technological development, Latin America has relied heavily on foreign capital and technology and remained dependent on the developed world (AMSDEN, 1989; CHANG, 2003; EVANS, 1980; KOHLI, 2009). Latin American countries have given excessive importance to foreign capital, which has been assigned the role of increasing the technological capability of the region by supporting product and process innovations produced by transnational companies (KATZ, 2000). The entrance of foreign direct investment (FDI) into the region has created profound economic segmentation by enhancing structural heterogeneity (FURTADO, 1959) and feeding a 'modernizationmarginalization' duality (FURTADO apud ALBUQUERQUE, 2005) that is characterized by high levels of inequality and informality (OECD, 2018). In addition, time has shown that the emphasis on technology imports to the detriment of local development (with the expectation that the growth of transnational participation would result in technology transfers) has proven this policy to be a failure in overcoming underdevelopment (ERBER, 2000).

The existence of domestic companies and powerful MNCs in Latin America lies at the core of the political obstacles to building the institutions necessary to 
implement upgrading policies in the region ${ }^{3}$ (ALBUQUERQUE, 2005; FURTADO, 1987). Without sustained and cohesive support from a broad segment of BBs, it is especially difficult to build high-cost, long-term upgrading institutions, especially in democratic settings where short-term political thinking weakens incentives for long-term investment (DONER and SCHNEIDER, 2019, 2016).

Moreover, there is a correlation between the heterogeneity of the structures in place and the proliferation of obstacles to the building of coalitions around common institutions, especially in respect of two fields that are essential for economic upgrading: education (human capital) and Research and Development (R\&D). The former is a particularly interesting case and has been extensively explored in the literature (DONER and SCHNEIDER, 2019, 2016).

There is a universal consensus on the need for more and better education in order to foster economic development. However, most LDCs have not made a major effort to advance their education policies. The absence of effective measures to improve education can be explained by the absence of a unified voice or any political force that could support massive investments in education (DONER and SCHNEIDER, 2019, 2016). In effect, although almost all BBs complain about a lack of skilled workers, their real need is too feeble to support any governmental imposition of the heavy costs that would be needed to improve the quality of education.

As for domestic BBs, most of them tend to be most competitive in the areas of commodities (petroleum, agro-industry, minerals and metals, etc), lowtechnology manufacturing (food, beverages and clothing) and low-complexity services (utilities). Such sectors generally require small numbers of highly-skilled workers and large numbers of less-skilled workers. When specific knowledge is needed, firms can pay for in-house training.

By contrast, MNCs are more competitive in high-technology sectors and demand more skilled labor. However, they have the advantage of moving relatively more complex activities to places where more highly qualified and skilled human capital is abundant. When MNCs do need to hire skilled labor (especially when workers are less mobile due to the locations of natural resources or large domestic 
markets), they have the advantage of offering higher wages than local businesses or attracting employees directly from prestigious universities (HEYES and RAINBIRD, 2011). Indeed, empirical evidence demonstrates that MNCs routinely provide higher wages in LDCs than their local counterparts do (BROWN, DEARDORFF, and STERN, 2003).

A similar argument can be made regarding the demand-side for innovation. Increasing investment in $\mathrm{R} \& \mathrm{D}$ is widely recognized as key to overcoming underdevelopment. As in education, R\&D investments cannot be achieved overnight: they require a range of institutions that promote cooperation among universities and business, property rights protection, innovation financing, technical training and so on.

Generally, countries with the highest levels of gross expenditure on R\&D (GERD) are the ones with the highest private sector participation in R\&D (Table 01) funding. In South Korea and Japan, private expenditure represented more than 76\% of total GERD (in 2017), and both countries' R\&D investments represent more than 03\% of GDP. In Latin America, by contrast, the innovation shortfall is accompanied by a lack of private R\&D investment. In Argentina and Mexico, the private sector accounts lass then $20 \%$ of total GERD (in 2017), followed by Chile (31.43\%) and Brazil (47.46\%). The GERD as a percentage of the GDP in those countries has settled at less than 01\% (except in Brazil, which has maintained its GERD/GDP at around 01\%). Incredibly, China increased its GERD from 0.89 in 2000 to 2.15 in 2017. This increase, while coordinated by the central government, was pushed by the private sector and resulted in a jump from $57.59 \%$ to $76.48 \%$ of the country's total GERD.

Low levels of private investment in R\&D are one of several signs of a weak NSI. This weakness is particularly problematic in light of the high vulnerability of public revenues in middle-income countries. Latin American firms cannot rely on public support for long-term innovation projects, except those that are ringfenced against budget cuts, which are frequent occurrences and de rigueur upon a change of government. Firms cannot invest in additional R\&D if the duration of government support is uncertain (GUELLEC and POTTERIE, 2003). 
Table 01. GERD as a share of GDP and GERD funded by private businesses, selected countries and years

\begin{tabular}{|c|c|c|c|c|c|c|c|c|c|c|}
\hline \multirow[b]{3}{*}{ European Union** } & \multicolumn{5}{|c|}{ GERD, $\%$ of GDP } & \multicolumn{5}{|c|}{$\begin{array}{l}\text { Percentage of GERD funded by } \\
\text { the private sector }\end{array}$} \\
\hline & 2000 & 2005 & 2010 & 2015 & 2017 & 2000 & 2005 & 2010 & 2015 & 2017 \\
\hline & 1.75 & 1.78 & 1.97 & 2.12 & 2.13 & 55.36 & 53.71 & 53.15 & 54.64 & 57.60 \\
\hline OECD & 2.27 & 2.20 & 2.36 & 2.44 & 2.56 & 64.08 & 62.24 & 58.50 & 61.41 & 62.33 \\
\hline UK & 1.63 & 1.56 & 1.66 & 1.67 & 1.66 & 48.31 & 42.06 & 44.05 & 48.96 & $51.77^{*}$ \\
\hline USA & 2.62 & 2.51 & 2.74 & 2.72 & 2.79 & 69.03 & 63.31 & 56.93 & 62.54 & 62.48 \\
\hline France & 2.09 & 2.05 & 2.18 & 2.27 & 2.19 & 52.52 & 51.93 & 53.50 & 54.04 & 56.08 \\
\hline Germany & 2.39 & 2.42 & 2.71 & 2.91 & 3.02 & 65.85 & 67.51 & 65.52 & 65.58 & 66.18 \\
\hline Middle Income & 0.64 & 0.84 & 1.11 & 1.36 & 1.52 & - & - & - & - & - \\
\hline Latin America & 0.57 & 0.59 & 0.75 & 0.78 & $0.74^{*}$ & - & - & - & - & - \\
\hline Argentina & 0.44 & 0.42 & 0.56 & 0.62 & 0.54 & 23.28 & 31.02 & - & 17.22 & 16.52 \\
\hline Brazil & 1.00 & 1.00 & 1.16 & 1.34 & 1.26 & 44.16 & 50.44 & 47.04 & 45.55 & 47.46 \\
\hline Chile & - & - & 0.33 & 0.38 & $0.36^{*}$ & - & - & 25.44 & 32.77 & 31.43 \\
\hline Mexico & 0.31 & 0.40 & 0.53 & 0.52 & $0.49 *$ & 29.52 & 41.51 & 33.02 & 17.38 & 19.05 \\
\hline China & 0.89 & 1.31 & 1.71 & 2.07 & 2.15 & 57.59 & 67.04 & 71.69 & 74.73 & 76.48 \\
\hline Japan & 2.91 & 3.18 & 3.14 & 3.28 & 3.21 & 72.42 & 76.12 & 75.93 & 77.97 & 78.27 \\
\hline South Korea & 2.18 & 2.63 & 3.47 & 4.22 & 4.55 & 72.38 & 74.96 & 71.80 & 74.55 & 76.23 \\
\hline
\end{tabular}

Source: The authors' own. Data sourced from the World Bank regarding GERD/GDP and from the OECD regarding GERD funded by the private sector. Dada regarding GERD funded by private sector in Argentina, Brazil and China was sourced by the Brazilian Ministry of Science, Technology, Innovations and Communications.

Note: $\left({ }^{*}\right)$ data for $\left.2016 ;{ }^{* *}\right) 28$ countries.

Here again the split between big domestic and MNCs de-incentivizes private investment in R\&D. Although MNCs might be willing to support and even benefit from the local NSI, they always have the option of relying on the ST\&I actors available at home or simply obtaining what they need from elsewhere, especially from somewhere whose NSI is mature. Despite increases in R\&D performed abroad, many studies have shown that most such activities remain concentrated in MNCs' home countries (ZACHAREWICZ, SANZ-MENÉNDEZ, and JONKERS, 2017) and that MNCs have few incentives to base their R\&D activities abroad, given that no more than $10 \%$ of their technological effort takes place overseas (ARCHIBUGI and PIETROBELLI, 2003).

To illustrate the previous discussion, it is interesting to look at some figures relating to the U.S. case, as U.S. companies are those that invest the most in domestic activities to develop new technologies through R\&D, being far ahead of Japanese, German, French and British companies in this respect (CHIARINI, 2017). U.S. private R\&D abroad is continually increasing (CHIARINI et al., 2020; LAURENS et al., 2015; NSB, 2016). Investments in $R \& D$ in the host countries of majority-owned foreign affiliates of U.S. parent companies account for only about $9.0 \%$ of the total R\&D 
performed in the U.S. (average for the 1997-2017 period). Figure 01 shows the increase trend of U.S. GERD and U.S. R\&D invested abroad.

In Latin America, FDI is characterized by an inverse statistical relationship with R\&D investment (CRESPI, TACSIR, and VARGAS, 2016), which corroborates the finding of other studies conducted in the region that MNCs do not develop disruptive technologies locally (CRESPI and ZUÑIGA, 2012; PAGÉS, 2010; RAFFO, LHUILLERY, and MIOTTI, 2008). Still in respect of the U.S. case, one can see that while Latin America receives a considerable amount of U.S. FDI investment (16.76\% in 2017), it receives only a small amount for R\&D activities (3.95\% in 2017). On the other hand, the European Union receives the lion's share of both total U.S. FDI abroad (59.09\%) and U.S. R\&D captive offshoring (48.39\% in 2017) (Table 02).

Domestic businesses in Latin America have evolved in a productive structure that provides few incentives to innovate. Many of them were able to grow and survive in sectors free of pressure to build innovative capabilities. The kind of R\&D carried out by domestic firms is commonly oriented towards innovative processes and products for the domestic market rather than cutting-edge technologies. Their efforts to innovate tend to be even more tepid than those of MNCs (ZUCOLOTO and CASSIOLATO, 2013).

Low demand for innovation reinforces the mismatch between the production of knowledge and technology in the region. Consequently, the increase in scientific output observed in the last decade (measured by the participation of Latin American countries in the worldwide publication of scientific papers) has not been accompanied by an increase in patent applications, which suggests that private sector demand has not evolved at the same pace as scientific supply (DUTRÉNIT and ARZA, 2015). To illustrate this, we have depicted in Figure 02 the values for scientific and technical journal articles published, and patent applications registered, per million inhabitants for selected countries. It is interesting to note that Latin American countries are clustered at the bottom left of the graph, which shows that Latin American scientific papers and patent applications are scarce in comparison with those from more developed countries.

Weak demand for higher-quality education (DONER and SCHNEIDER, 2019), combined with scarce private expenditure on R\&D call into question the capacity of business incumbents to invest in NSIs in Latin America. It is true that the direction 
of causality remains controversial. Is the lack of business investment in R\&D attributable to the absence of institutional framing or is it the case that failure to invest in institution building can be put down to weak demand for R\&D? In this article, we shall take a detour off the conventional path followed by NSI scholars who tend towards the former explanation - and propose that the latter be explored.

Chang (2007) notes that in spite of a wide consensus on the idea of coevolution between the 'mode of production' of a society and institutions, historical observation endorses the argument that it is very difficult to create new institutions through political means alone. The introduction of new economic activities that increase demand for different kinds of institutions has proved more efficient in driving institutional change. However, in periods of radical technological change (CHANG, 2007), it is natural to see institutional inertia serving as a roadblock as it protects the status quo.

Figure 01. U.S. GERD and U.S. R\&D offshore, 1997-2017

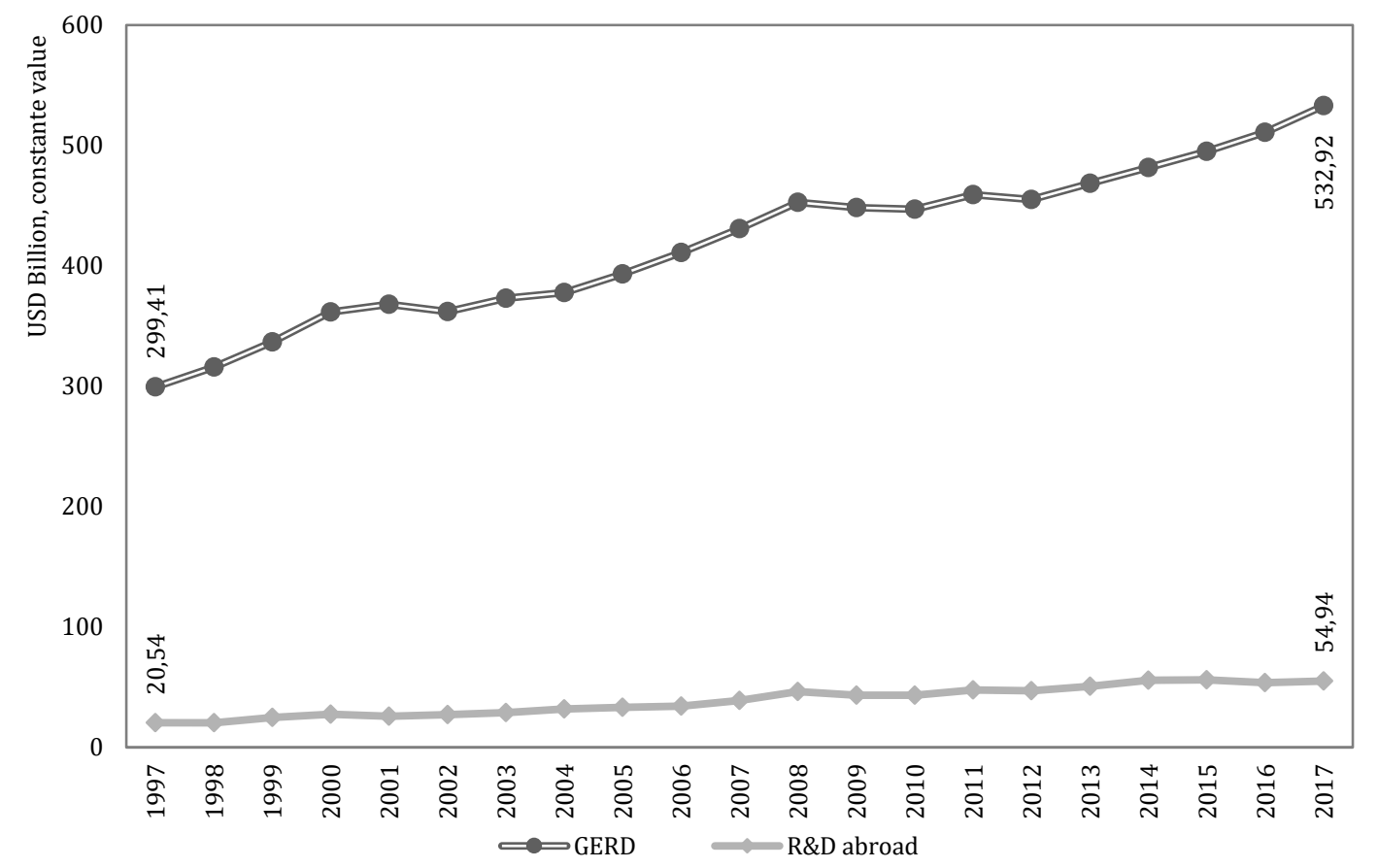

Source: The authors' own. Data sourced from OECD and from the Bureau of Economic Analysis (https://www.bea.gov/).Note: Current USD values were deflated using the GDP deflator (year base 2015), data available from the World Bank. 
Table 02. U.S. direct investment and U.S. R\&D performed abroad, share in relation to total, selected countries, selected years

\begin{tabular}{lcccccccccc}
\hline & \multicolumn{3}{c}{$\begin{array}{c}\text { U.S. direct investment position abroad on } \\
\text { historical-cost basis (all industries) }\end{array}$} & \multicolumn{3}{c}{ R\&D performed abroad by majority-owned foreign affiliates of U.S. } \\
parent companies \\
(all industries)
\end{tabular}

Source: The authors' own. Data sourced from the Bureau of Economic Analysis, Survey of U.S. Direct Investment Abroad (annual series).

Note: $\left({ }^{*}\right)$ value for 2007; $\left({ }^{* *}\right)$ Absolute value is in millions of constant U.S. dollars. Current U.S. dollars were deflated by the GDP deflator (year base 2015) available from the World Bank database. 
The picture here resembles the argument put forward by Acemoglu, Johnson, and Robinson (2005), who point out that producers are the main 'demanders' of institutions to foster economic activity. Yet, at the same time that they demand institutions to protect their property rights, they erect barriers against the entry of new entrepreneurs, thereby blocking economic development (ACEMOGLU, 2008). Once established, incumbent businesses prefer to maintain the barriers to entry, thereby inhibiting the access on the part of newcomers to skilled labor and technology so as to defend their incomes (PRZEWORSKI, 2007).

What makes this line of argument tricky for Latin America is that incumbent businesses drive innovation in the region and should therefore demand the strengthening of the NSI. Moreover, considering their privileged bargaining position, it would not be difficult for BBs to unify their demands and coordinate lobbying in favor of a strong NSI (FAIRFIELD, 2013; SANTOS, 2014). The argument to be corroborated is whether BBs in Latin America are active supporters or active blockers of strengthening the NSI.

Figure 02. Scientific and technical journal articles published, and patents filed per million inhabitants, 2015, selected countries

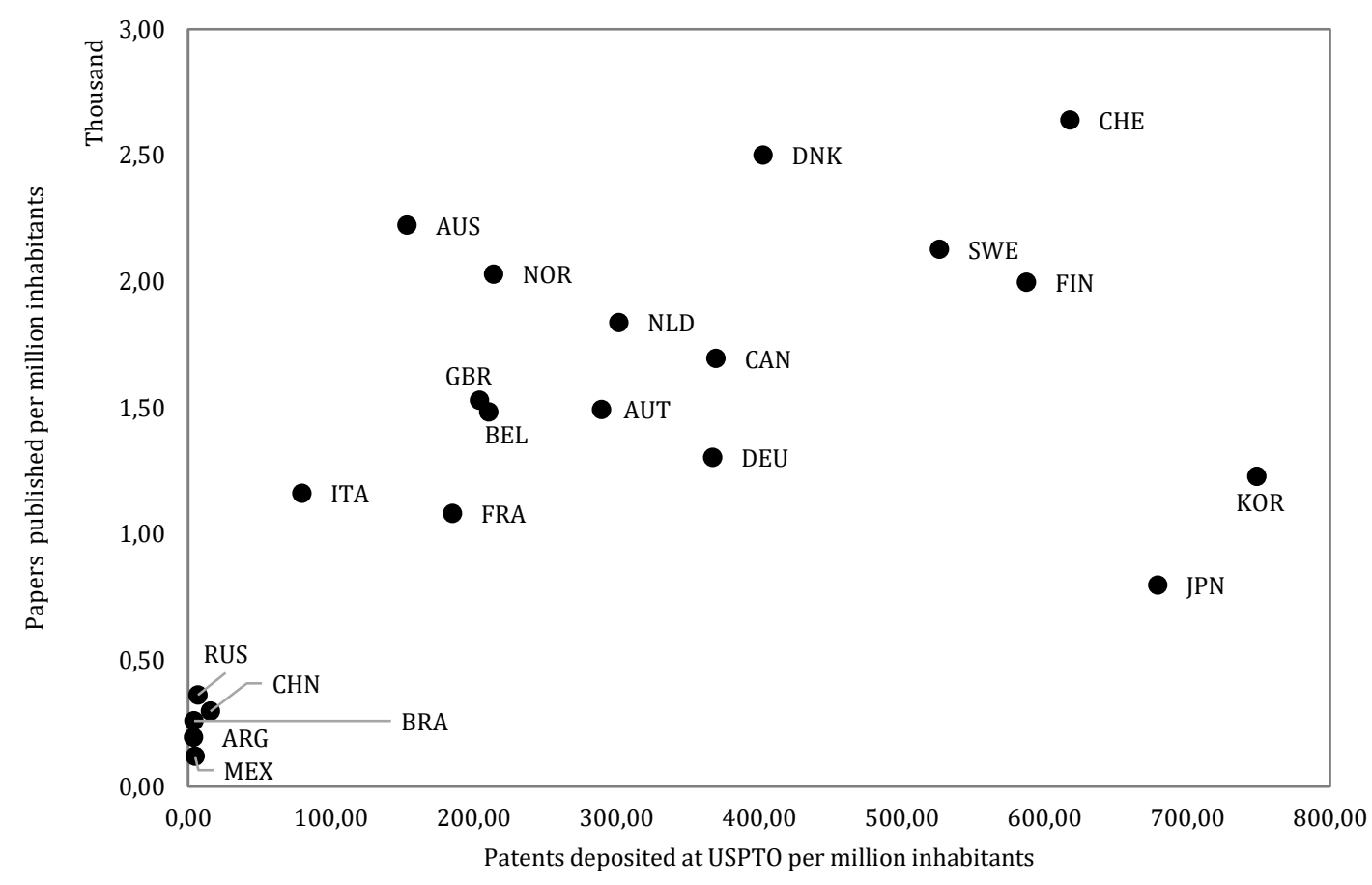

Source: The authors' own. Data sourced from the World Bank and from USPTO.

Note: 'Scientific and technical journal articles' denotes scientific and engineering articles published in the following fields: physics, biology, chemistry, mathematics, clinical medicine, biomedical research, engineering and technology, as well as earth and space sciences. 
In the following sections, we expand the framework proposed by Doner and Schneider $(2019,2016)$ to shed light on the participation of BBs in upgrading coalitions in Brazil. Focusing on both public and private initiatives, we analyze the political obstacles that impede Brazil in its climb up the technology ladder.

\section{Mismatches within the public sector}

Brazil industrialized rapidly in the period between 1930 and 1980. Briefly, we can say that Brazil has been able to build a relatively diversified and integrated productive structure based on the welcoming of MNCs and on the establishment of big public companies (DAHLMAN and FRISCHTAK, 1990) such as in the oil and gas, metal-mechanical and chemical sectors. Nonetheless, there is a consensus that Brazil formulated no comprehensive policy strategy for the absorption of productive knowledge by domestic private businesses, and that emphasis was instead placed on the role of public enterprises and public research laboratories. The domestic private sector was not considered important to the innovation process and their efforts were limited to the adaptation of products and processes contingent on the importation of machinery and equipment, or the spillover effects of state-owned or multinational enterprises (KATZ, 2000).

Brazil has also achieved relatively vigorous scientific production vis-à-vis counterpart countries and has succeeded in establishing a considerable number of ST\&I institutions with the enforcement of a reasonable intellectual property rights protection system (MAZZUCATO and PENNA, 2016). However, the two actors - forprofit companies and universities - were always separate and had weak relationships. Instead, Brazil had so-called 'islands of innovation', especially in respect of relationships between publicly-owned laboratories and companies (SUZIGAN and ALBUQUERQUE, 2011). 
In the last two decades, governments with divergent ideologies ${ }^{4}$ have taken important steps to foster ST\&I activities and spur innovation. During this time, a myriad of institutional arrangement such as National Acts, Decrees, Programs, Action Plans and Strategic Plans (Table 03) have been put in place, while a constitutional amendment was promulgated that altered the text related to ST\&I activities in order to highlight their role in innovation processes (85A). This resulted in the then 'S\&T Ministry' (MCT) becoming the 'ST\&I Ministry' (MCTI).

Probably one of the main contributions of the last decades in respect of ST\&I policies was the design of a new funding mechanism based on sectoral funds. These funds were conceived to answer industry needs for innovationoriented research (PACHECO, 2019; PELAEZ et al., 2017; SÁ, 2005) and promote financial resource stability in the Brazilian Innovation System (PEREIRA, 2005; SZAPIRO, VARGAS, and CASSIOLATO, 2016). In total, sixteen funds were formed: there were thirteen thematic funds - oil and natural gas; energy; transportation; hydro resources; mineral resources; aerospace; telecommunications; information technology; biotechnology; agribusiness; health; audiovisual; and aeronautics - and three horizontal funds - the university-industry collaboration fund; the Amazon fund; and the infrastructure fund.

Other institutional advancements include the creation of a handful of legal instruments to deal with different aspects of the Brazilian Innovation System: to facilitate university-industry interactions; to reduce bureaucratic procedures that hamper public-private cooperation focused on R\&D activities; to provide legal support and set incentives for the commercialization of the results of scientific and technological research developed in public universities and research institutes; and to allow tax exemptions on corporate investments in R\&D - the so called 'Innovation Act', the 'Lei do Bem' and the 'New Computing Act'.

\footnotetext{
${ }^{4}$ Luiz Inácio Lula da Silva of the Workers' Party (Partido dos Trabalhadores, PT) was the democratically elected president of Brazil for two consecutive terms, from 2003 to 2010. Lula is considered one of the most popular politicians in Brazilian history, and his terms of government became known for their social programs. Before Lula, Fernando Henrique Cardoso (FHC) served for two terms as president of Brazil, from 1995 to 2002. Important features of the Cardoso administrations include the stabilization of monetary policies and the deepening of privatization programs. Cardoso is identified with neoliberalism and right-wing politics. Lula supported the candidacy of Dilma Rousseff, who was inaugurated in 2011 as the first female president of Brazil and was reelected for a second term, which was to run from 2015 to 2018. In 2016, Rousseff was accused of criminal administrative misconduct and was impeached and replaced by her vice president, Michel Temer, who remained in office until 2019, when ultra-conservative far-right populist Jair Bolsonaro, who had won the 2018 presidential election, took office.
} 
Table 03. Milestones in ST\&I institutional advancements in Brazil, from the mid-1990s to late 2010

\begin{tabular}{|c|c|c|c|}
\hline Governments & $\begin{array}{l}\text { Institutional } \\
\text { Instruments }\end{array}$ & $\begin{array}{l}\text { Publication } \\
\text { year }\end{array}$ & Brief description \\
\hline President & Law 9,478 & 1997 & Creation of Oil and Natural Gas Sector Fund (CT-Petro) \\
\hline Cardoso & Law 9,991 & 2000 & Creation of Energy Sector Fund (CT-Energ) \\
\hline \multirow[t]{16}{*}{$(1995-2002)$} & Law 9,992 & 2000 & Creation of Transportation Sector Fund (CT-Transp) \\
\hline & \multirow[t]{2}{*}{ Law 9,993 } & \multirow[t]{2}{*}{2000} & Creation of Hydro Resources Sector Fund (CT-Hidro) \\
\hline & & & Creation of Mineral Resources Sector Fund (CT-Mineral) \\
\hline & Law 9,994 & 2000 & Creation of Aerospace Sector Fund (CT-Espacial) \\
\hline & Law 10,052 & 2000 & Creation of Telecommunications Sector Fund (FUNTTEL) \\
\hline & Law 10,168 & 2000 & $\begin{array}{l}\text { Creation of University-Industry Collaboration Fund (Fundo } \\
\text { Verde Amarelo) }\end{array}$ \\
\hline & Law 10,197 & 2001 & Creation of R\&D Infrastructure Fund (CT-Infra) \\
\hline & \multirow[t]{2}{*}{ Law 10,176 } & \multirow[t]{2}{*}{2001} & Creation of Information Technology Sector Fund (CT-Info) \\
\hline & & & Creation of Amazon Sector Fund (CT-Amazônia) \\
\hline & Law 10,260 & 2001 & Creation of Higher Education Student Fund (FIES) \\
\hline & \multirow[t]{4}{*}{ Law 10,332} & \multirow[t]{4}{*}{2001} & Creation of Biotechnology Sector Fund (CT-Bio) \\
\hline & & & Creation of Agribusiness Sector Fund (CT-Agro) \\
\hline & & & Creation of Health Sector Fund (CT-Saúde) \\
\hline & & & Creation of Aeronautics Sector Fund (CT-Aeronáutico) \\
\hline & Decree & 2002 & Creation of the Center for Management and Strategic \\
\hline & 4,078 & & Studies (CGEE) \\
\hline \multirow{17}{*}{$\begin{array}{l}\text { President } \\
\text { Lula } \\
(2003-2010)\end{array}$} & Law 10,973 & 2004 & Innovation Act (Lei da Inovação) \\
\hline & Law 11,077 & 2004 & New Computing Act (Nova Lei da Informática) \\
\hline & \multirow[t]{2}{*}{ Law 11,080} & \multirow[t]{2}{*}{2004} & $\begin{array}{l}\text { Creation of the Brazilian Agency for Industrial Development } \\
\text { (ABDI) }\end{array}$ \\
\hline & & & $\begin{array}{l}\text { Creation of the National Industrial Development Council } \\
\text { (CNDI) }\end{array}$ \\
\hline & Law 11,096 & 2005 & Creation of University for All Program (PROUNI) \\
\hline & Law 11,105 & 2005 & Biosecurity Act (Lei da Biossegurança) \\
\hline & Law 11,196 & 2005 & Good Act (Lei do Bem) \\
\hline & Law 11,437 & 2006 & Creation of Audiovisual Sector Fund (FSA) \\
\hline & Law 11,487 & 2007 & $\begin{array}{l}\text { New incentive for technological innovation and new rules to } \\
\text { speed up amortization of R\&D investments }\end{array}$ \\
\hline & Action Plan & 2007 & Action Plan for ST\&I (PACTI) 2007-2010 \\
\hline & Decree & 2007 & Creation of the Biotechnology Development Program \\
\hline & \multicolumn{3}{|r|}{ 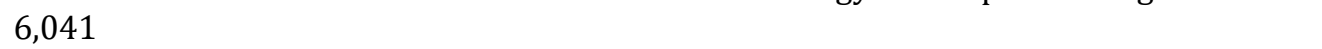 } \\
\hline & Decree & \multirow[t]{2}{*}{2007} & Creation of Federal University Restructuring \& Expansion \\
\hline & 6,096 & & Program (PROUNI) \\
\hline & Decree & \multirow[t]{2}{*}{2007} & \multirow[t]{2}{*}{ Creation of the Brazilian Technology System (SIBRATEC) } \\
\hline & 6,259 & & \\
\hline & Law 11,892 & 2008 & $\begin{array}{l}\text { Creation of Federal Institutes of Education, Science and } \\
\text { Technology (IFETs) }\end{array}$ \\
\hline \multirow{11}{*}{$\begin{array}{l}\text { President } \\
\text { Rousseff } \\
(2011-2016)\end{array}$} & 541PM & 2011 & 'S\&T Ministry' became 'ST\&I Ministry' \\
\hline & Decree & \multirow[t]{2}{*}{2011} & Creation of Science Without Borders Program (Ciência sem \\
\hline & 7,642 & & Fronteira) \\
\hline & Action Plan & 2011 & Creation of Innovate Company (Inova Empresa) \\
\hline & $\begin{array}{l}\text { Decree } \\
7,819\end{array}$ & 2012 & $\begin{array}{l}\text { Creation of Inovar-Auto Program to support innovation for } \\
\text { automotive sector }\end{array}$ \\
\hline & $\begin{array}{l}\text { Strategic } \\
\text { Plan }\end{array}$ & 2012 & National Strategy for ST\&I (ENCTI) 2012-2015 \\
\hline & Decree & \multirow[t]{2}{*}{2013} & Creation of the Brazilian Enterprise for Research and \\
\hline & 02.09 & & Industrial Innovation (Embrapii) \\
\hline & Decree & \multirow[t]{2}{*}{2014} & \multirow[t]{2}{*}{ Creation of the National Knowledge Platform Program } \\
\hline & 8,269 & & \\
\hline & Law 13,123 & 2015 & Biodiversity Act (Lei da Biodiversidade) \\
\hline
\end{tabular}




\begin{tabular}{|c|c|c|c|}
\hline & \multicolumn{2}{|c|}{ bpsr } & $\begin{array}{l}\text { - Tulio Chiarini, Fernanda Cimini, Marcia } \\
\text { Siqueira Rapini \& Leandro Alves Silva }\end{array}$ \\
\hline & $85 \mathrm{~A}$ & 2015 & $\begin{array}{l}\text { Constitutional amendment which updates the treatment of } \\
\text { ST\&I activities }\end{array}$ \\
\hline & 694PM & 2015 & Reduction of fiscal incentives proposed by Good Act \\
\hline & $\begin{array}{l}\text { Strategic } \\
\text { Plan }\end{array}$ & 2015 & National Strategy for ST\&I (ENCTI) 2015-2019 \\
\hline & Decree & 2016 & Increases the production rate of Brazilian suppliers of oil \\
\hline & 8,637 & & and gas sector through technological innovation \\
\hline & Law 13,243 & 2016 & Legal Framework for ST\&I Act (Marco Legal da Inovação) \\
\hline \multirow{2}{*}{$\begin{array}{l}\text { President } \\
\text { Temer } \\
(2016-2018)\end{array}$} & $95 \mathrm{~A}$ & 2016 & $\begin{array}{l}\text { Constitutional amendment capping public spending for the } \\
\text { next two decades }\end{array}$ \\
\hline & $\begin{array}{l}\text { Decree } \\
8.898\end{array}$ & 2016 & $\begin{array}{l}\text { Regulates the ST\&I National Council that advises the } \\
\text { President on the formulation and implementation of ST\&I } \\
\text { policies }\end{array}$ \\
\hline $\begin{array}{l}\text { President } \\
\text { Bolsonaro } \\
\text { (2019-?) }\end{array}$ & - & 2019 & $\begin{array}{l}\text { Entrepreneurial and Innovative Institutes and Universities } \\
\text { Program (Future-se) }\end{array}$ \\
\hline
\end{tabular}

Source: Authors' own.

Moreover, there was a great effort to boost the performance of such public financing institutions as the National Bank of Economic and Social Development $^{5}$, the Finance Agency of Studies and Projects ${ }^{6}$, (BASTOS, 2012) national ST\&I funding agencies, and the Brazilian Enterprise for Research and Industrial Innovation ${ }^{7}$. Moreover, other agencies were created to provide better coordination between pro-innovation initiatives and provide interaction with other institutions (STEIN and HERRLEIN-JR., 2016; TONI, 2007), such as the establishment of the Brazilian Industrial Development Agency ${ }^{8}$ whose aim was to promote the implementation of industrial policies, especially those contributing to job creation, in line with the foreign trade and ST\&I policies and the National Industrial Development Council ${ }^{9}$ with a view to at advising the president on specific policies and other measures to promote industrial development in Brazil (Law 11,080 of December 30, 2004; Table 03).

It is also interesting to note that national ST\&I strategies were also put in place during this period. The 2015 strategy publication (ENCTI 2015-2019), acknowledged that a determining factor for the success of nations in fostering innovation was the creation of a strong and articulated NSI capable of mobilizing actors and instruments in a consistent and result-oriented manner that would generate socio-economic benefits.

\footnotetext{
${ }^{5}$ Banco Nacional de Desenvolvimento Econômico e Social, BNDES.

${ }^{6}$ Financiadora de Estudos e Projetos, FINEP.

${ }^{7}$ Empresa Brasileira de Pesquisa e Inovação Industrial, Embrapii.

${ }^{8}$ Agência Brasileira de Desenvolvimento Industrial, ABDI.

${ }^{9}$ Conselho Nacional de Desenvolvimento Industrial, CNDI.
} 
Despite there being no doubt Brazil has built a diversified set of ST\&I policies and programs, it faces two paramount challenges that are of concern to us. First, there is a lack of articulation and coordination between actors and instruments within the Brazilian government. Studies have shown that Brazil lacks a clear coordination between such instruments and other government initiatives within government itself (NEGRI and RAUEN, 2018; SUZIGAN, GARCIA, and FEITOSA, 2020; ZUÑIGA et al., 2016).

These coordination failures across innovation policies were identified in a report by the Federal Court of Accounts ${ }^{10}$, which was one of the first such publications on the role of Brazilian public agencies and entities in the context of the NSI and whose subject was not a specific program, but the innovation agenda (TCU, 2018). According to the report, Brazil lacks an active government coordination structure for pro-innovation policies. Pro-innovation programs and action plans are spread throughout diverse ministries due to their transversal character and there is no clear definition of how they should be coordinated with national policies. The coordination responsibilities of federal public policies for innovation are not clearly defined between the ST\&I Ministry and other ministries in a whole-ofgovernment approach (TCU, 2018).

Second, the Brazilian ST\&I agenda is unstable. To highlight the instability of the ST\&I agenda, some scholars (PACHECO, 2019; PELAEZ et al., 2017) have proposed looking at the terms of office of ST\&I Ministers and Industry and Commerce Ministers, who are responsible for proposing policies in this field (Figure 03). They show that the irregularity of ministerial terms of office goes a long way to explain recurrent discontinuities in industrial and ST\&I policies.

Ministers of Science and Technology (...) and Industry and Commerce (...), responsible respectively for ST\&I and industrial policy-making, spend an average of 1.5 years in office. They rarely spent even half of a President's four-year term, and most last less than 12 months. This illustrates the extreme volatility of public-policy making and coordination in these areas of government (PELAEZ et al., 2017, p. 800).

The churn rates for ST\&I Ministers and Industry and Ministers indicate that innovation policies were also subject to the pressures of Brazilian 'coalitional presidentialism', which reinforces fragmentation of the ST\&I agenda (LIMOEIRO

${ }^{10}$ Tribunal de Contas da União, abbreviated as TCU. 
and SCHNEIDER, 2017). It is possible to see from Figure 03 that ST\&I Ministry churn reached its peak during the Rousseff administration when a political crisis dominated in Brazil and the political command system crumbled. As correctly stated by Pelaez, this means that "long-term political agendas are rarely set, while it also holds back the formation of skills needed to balance all the different interests at stake"(PELAEZ et al., 2017, p. 801). As a consequence the ST\&I Ministry is a weak ministry with poor coordination capacity (PACHECO, 2019).

Still looking at the ST\&I agenda instability, we now turn our gaze to the Annual Budget Law (Lei Orçamentária Anual ((LOA) ${ }^{11}$ ) for key ST\&I activities: 01. the 'Higher Education Program' of the Office for the Improvement of Higher Level Personnel ${ }^{12}$ (Capes); 02. the 'ST\&I Program' of the National Council for Scientific and Technological Development ${ }^{13}$ (CNPq); and 03. the Sectoral Funds ${ }^{14}$ (FNDCT).

According to Pelaez el al. (2017), the Brazilian dependency on macroeconomic stabilization goals has perpetuated the government's habit of cutting back Sectoral Funds (FNDCT) and prioritizing austerity over longterm industrial policy. Brazil suffers from a lack of coordination between long-term policy and its macroeconomic regime (NASSIF, BRESSER-PEREIRA, and FEIJO, 2018). In fact, it is not only the Sectoral Funds that suffer as a result of this habit, but also other ST\&I program budgets (Figure 04).

Dependency on macroeconomic stabilization goals is so rooted in Brazilian government that, faced with an economic crisis, President Rousseff submitted a Provisional Measure to Congress (694PM) to suspend the fiscal incentives for innovation presented set forth in the 'Lei do Bem' in order to increase government revenues. This measure was not approved by Congress but was enough to increase the legal uncertainty surrounding incentives to attract capital into R\&D activities. Also due to political crisis, Rousseff changed her ST\&I Minister six times between 2011 and 2015, which resulted in an average term of office of 10 months. This high churn rate is one of the causes of the "loss of credibility of the federal government

\footnotetext{
${ }^{11}$ The LOA estimates revenues and establishes the estimate of how much the Federal Government is authorized by Congress to spend throughout the year. As it is an estimate, the LOA can be amended by additional credit bills once congress approves provisional measures proposed by the president. Government expenditure can therefore vary from what was proposed by the LOA, however, this was not the case for the programs we analyze here.

${ }^{12}$ Coordenação de Aperfeiçoamento de Pessoal de Nível Superior, Capes.

${ }^{13}$ Conselho Nacional de Desenvolvimento Científico e Tecnológico, CNPq.

${ }^{14}$ Fundo Nacional de Desenvolvimento Científico e Tecnológico, FNDCT.
} 
concerning its capacity to create and implement a policy agenda able to stimulate public and private ST\&I investments" (PELAEZ et al., 2017, p. 802).

Since 2014, Brazil has experienced a change of policy direction towards austerity, which has led to reduced public investment and government expenditures, especially in strategic areas such as ST\&I. The Sectoral Fund budget estimate was reduced from USD 1.8 to USD 0.8 billion between 2014 and 2016 and, after the impeachment of President Rousseff, Congress approved a constitutional amendment (95A), capping public spending for 20 years (ROSSI and DWECK, 2016). The goal of this amendment was to control public debt and regain the confidence of foreign investors by capping the federal budget at the expenditure of the previous year, adjusted for inflation. The extent to which this measure will substantially affect the Brazilian NSI remains to be seen; however, the amendment has already led to a drastic cut in the federal ST\&I budget for key programs, as depicted in Figure 04.

\section{Mismatches within the private sector}

It is interesting to note that historically most innovation efforts in Brazil have not been performed by private big businesses. Indeed, by breaking down gross domestic expenditure on R\&D (GERD ${ }^{15}$ ) by fund source, we can see that the share financed by the public sector accounted for more than $50 \%$ in the last decades and reached its peak in 2013, when it accounted for 57.7\% of total GERD.

The diversified set of ST\&I policies, programs and action plans summarized in Table 03 in the previous section had a certain impact on the increase of the total GERD, however, this was mostly a result of the government's own expenditure on R\&D activities. Private businesses maintained their historically low level of R\&D intensity, which was not sufficient to increase their R\&D participation in total GERD. Looking at Figure 05, we can see that, while total GERD increased in absolute terms from 2000 to 2017 - especially during the Lula and Rousseff administrations - the GERD share financed by private businesses accounted for $47.16 \%$ of the total in $2000,47.46 \%$ in 2017

\footnotetext{
15The GERD consists of the total expenditure (current and capital) on R\&D by all resident companies, research institutes, university and government laboratories and so on. It excludes R\&D expenditure financed by domestic businesses but performed abroad.
}

$$
\text { (2020) } 14(2) \quad \text { e0001-20/39 }
$$


Figure 03. Terms of office of ST\&I ministers, in months

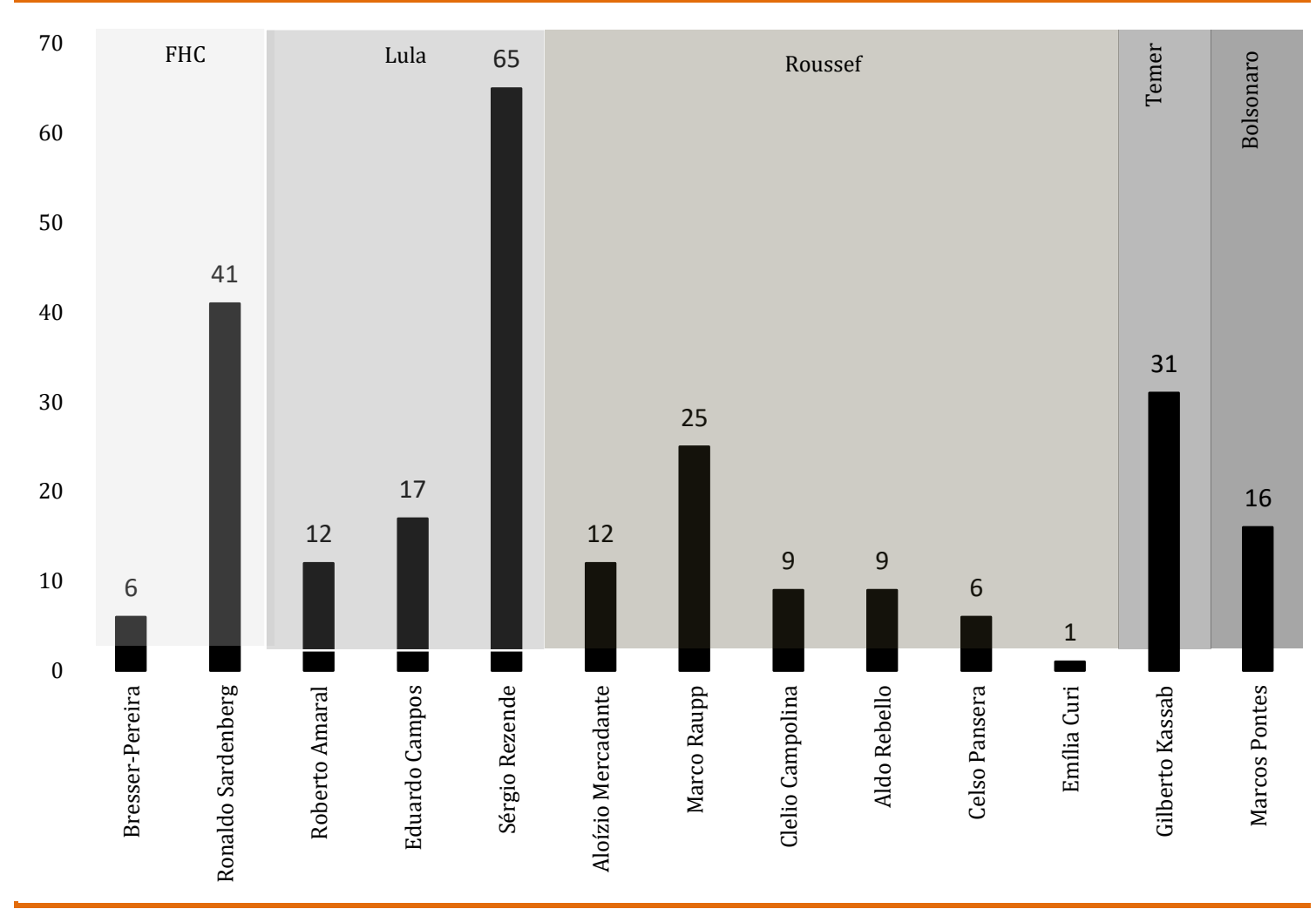

Source: Authors' own, based on Pelaez et al. (2017).

The GERD increase in the previous decades was accompanied by a persistent low innovation rate according to data from the Brazilian Innovation Survey (PINTEC), as can been seen in Table 04. The industrial innovation rate in the last decades has fluctuated but is always around 35\%. However, once we break down the data according to business size, the figures become more intriguing: BBs' rate of innovation has fallen from 72.55 to $67.31 \%$. Why is that?

Before trying to answer the previous question, it is important to take a closer look at the rate of innovation. In Table 05 and Table 06, we show that most of the innovation performed in Brazil is incremental rather than radical in nature, independently of the business size or type of innovation (i.e. product or process). However, even if the percentages of radical innovation (that is, products/processes that are completely new to international markets) are higher for BBs, they have not increased significantly over time. In fact, looking at Table 05, in which we present the degree of novelty of the main product brought onto the market by innovative industrial businesses, we can see that BBs' radical product innovation increased slightly from $5.74 \%$ to $7.43 \%$ over the course of a decade and 
a half. These figures, while reinforcing the importance of BBs as innovation leaders in Brazil, also suggest that BBs have not increased significantly their supply of innovative products to international markets. The same can be said about innovations in their production processes (Table 06).

Therefore, a possible answer to the previous question is that Brazilian BBs face more obstacles than they used to, in spite of all the National Acts, Decrees, Programs, Action Plans and Strategic Plans proposed to spur innovation. Indeed, once we look at the obstacles perceived by non-innovative BBs, we see that 'high innovation costs', 'excessive economic risks' and 'shortage of appropriate funding sources' continue to be the top three most highly perceived obstacles (Table 07).

Another possible answer to the previous question is that there is a lack of coordination between the public and private sectors in Brazil.

Figure 04. LOA expenditure estimation, 2000-2019

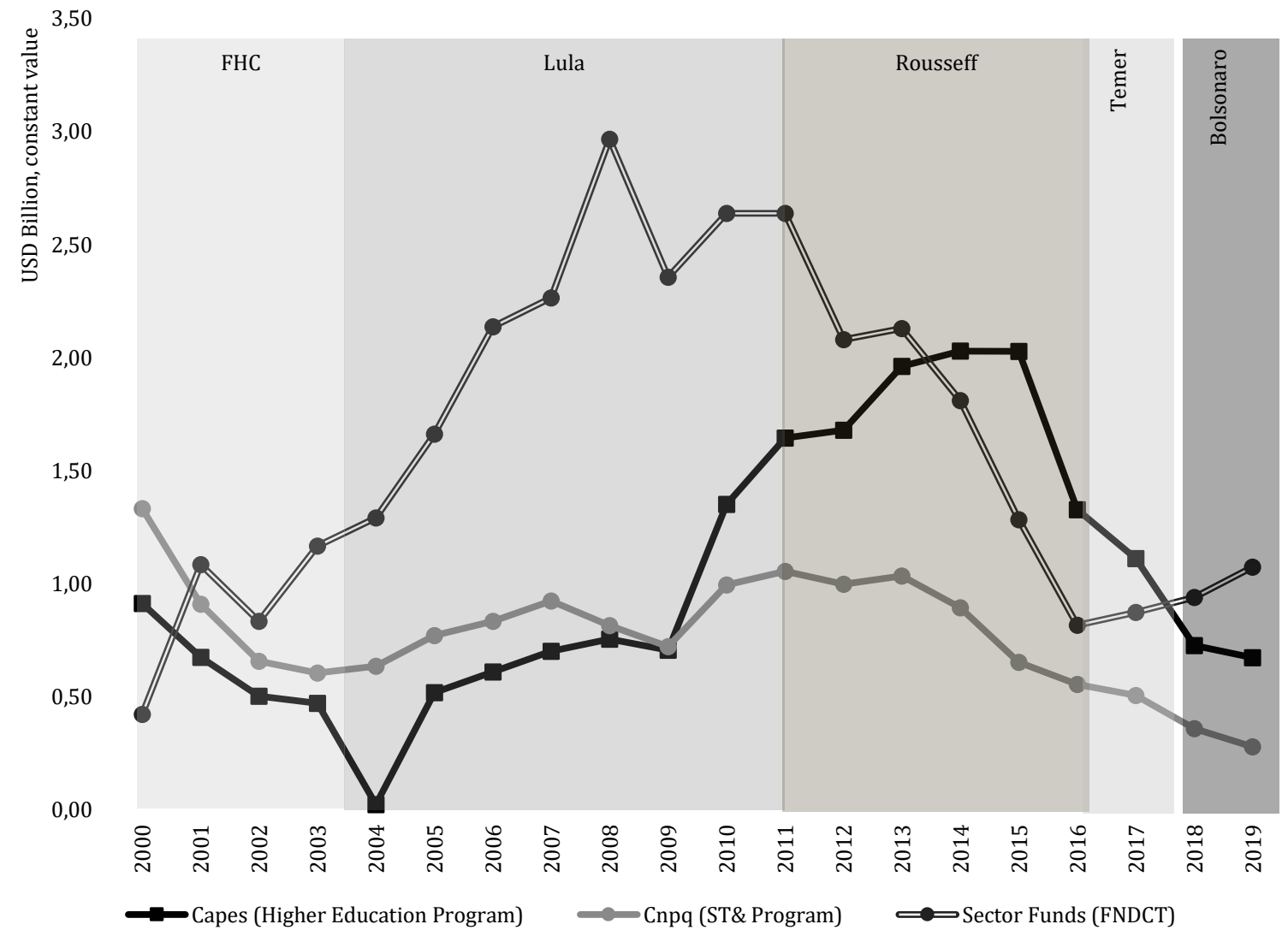

Source: The authors' own. Data sourced from the Ministério da Economia - Planejamento, Desenvolvimento e Gestão (www.planejamento.gov.br).

Note: Current BRL values were first deflated using the GDP deflator (year base 2018) and then converted into USD using the official exchange rate (year average); both sets of data were available from the World Bank database. 
Table 04. BB versus other size business, innovation indicators, industrial sector, 20032017

\begin{tabular}{llllll}
\hline & & 2003 & 2008 & 2014 & 2017 \\
\cline { 3 - 6 } Big & Innovation rate (\%) & 72.55 & 71.90 & 65.74 & 67.31 \\
businesses & Technological intensity (\%) & 0.68 & 0.80 & 0.77 & 0.72 \\
& R\&D/total innovative activities (\%) & 25.90 & 32.57 & 37.97 & 44.24 \\
Other size & Innovation rate (\%) & 32.63 & 37.54 & 35.94 & 33.30 \\
businesses & Technological intensity (\%) & 0.27 & 0.23 & 0.43 & 0.39 \\
& R\&D/total innovative activities (\%) & 12.52 & 8.54 & 18.49 & 22.62 \\
Big businesses interviewed & 1,364 & 1,660 & 1,968 & 1,735 \\
Other size businesses interviewed & 82,898 & 98,836 & 116,008 & 100,778 \\
Innovative big businesses & 989 & 1,194 & 1,294 & 1,168 \\
Innovative other size businesses & 27,047 & 37,105 & 41,694 & 33,564
\end{tabular}

Source: The authors' own. Data sourced from PINTEC/IBGE.

Note: Data regarding industrial sectors only. Technological intensity refers to share of total internal $\mathrm{R} \& \mathrm{D}$ in relation to total sales revenue.

One of the reasons for this lies at the heart of the dilemma described by Evans (1985) in relation to public intervention. On the one hand, effective intervention requires autonomy to protect public entities from the pressure of particularistic interests. On the other hand, autonomy ends up generating isolation from the productive domain and leading to uncoordinated actions. To solve this dilemma, Evans (1985) envisages the concept of 'embedded autonomy', and argues that a certain autonomy is necessary to formulate collective goals and cannot be disentangled from dense links with society, specifically with industrial capital, which in Brazil is mainly controlled by BBs (ALDRIGHI and POSTALI, 2010; LAZZARINI, 2018; SCHNEIDER, 2010). Brazil has been able to create 'pockets of efficiency' (EVANS, 1995) and has been very active in reviving industrial and innovation policies (SUZIGAN and FURTADO, 2010; TURCHI and MORAIS, 2017), but has not succeeded in building the relative autonomy necessary to balance private and public efforts (LIMOEIRO and SCHNEIDER, 2017).

An example of this lack of coordination can be observed in the mismatch between the public discourse of businesses associations favoring innovation and their effective lobbying in Congress. The Brazilian National Confederation of Industry (CNI16) encompasses the entire industrial sector, including both innovative and non-innovative companies. Not only is CNI the most relevant industrial association in the country; it is also the most prominent in the NSI. Besides

${ }^{16}$ Confederação Nacional da Indústria, CNI. 
its active engagement in vocational training - especially in relation to the so-called S-System ${ }^{17}$-, the CNI has set up the largest forum in Brazil for businessgovernment consultation on innovation. In 2008, the CNI invited CEOs of Brazilian BBs to establish the so-called 'Business Mobilization For Innovation' (MEI18). The MEI is made up of more than 200 executives and 153 companies. In the last ten years, their main achievements were successfully lobbying to include 'innovation' as a duty of the State in the Federal Constitution (85A), formulating and regulating of the Legal Framework for the ST\&I Act (Law 13,243) and keeping in place the 'i do Bem' (Law 11,196 of November, 21, 2005) ${ }^{19}$.

In 2019, the MEI launched its agenda for the following years (CNI, 2019), endorsing the need for prioritizing innovation in the public agenda along with better coordination between the highest level of government and business associations. Moreover, the MEI also called for budget stability for innovation, more training for the work force, internationalization of Brazilian universities and a reduced bureaucracy. However, these demands do not seem to be translated into lobbying activities, at least not in Congress. A brief overview of the Legislative Agenda of Industry - a document published annually that lists the main legislative activities affecting their interests - shows that the industrial agenda resembles the fragmentation of the public sphere. In the last 11 years (20082019), few proposals mentioned the public instruments listed in Table 03. The Biosecurity Act (Law 11,105 of March, 24, 2005) was the most frequently cited during this period, probably because of the commercial use of Genetically Modified organisms (GMOs), including the relaxation of marketing rules and food labeling.

The most important action related to the Innovation Act in the pipeline is a bill whose goal is to improve the performance of research institutes in ST\&I activities. Since 2016, the CNI has been following the course of this bill and supporting it with some reservations. Firstly, the CNI endorsed the need for

\footnotetext{
${ }^{17}$ S-System (i.e. a system of social contributions paid by companies: National Service of Rural Apprenticeship - SENAR; National Service of Trade Apprenticeship - SENAC; National Trade Social Service - SESC; National Service of Cooperative Apprenticeship - SESCOOP; National Service of Industrial Apprenticeship - SENAI; Industry Social Service - SESI; Social Service of Transportation - SEST; National Service of Transportation Apprenticeship - SENAT; and Brazilian Service of Micro and Small Size Companies Support - SEBRAE). In 2013, the CNI supported the repurposing of the S-System with the creation of 23 SENAI Innovation Institutes. <http://institutos.senai.br/english.html>.

${ }^{18}$ Mobilização Empresarial pela Inovação,MEI.

${ }^{19}<$ https://bucket-gw-cni-static-cms-si.s3.amazonaws.com/media/filer_public/26/8e/268ea92c0e54-4050-a868-8cd0390fa64e/1-_mei_10_anos_-_horacio_piva.pdf>.
} 
exemptions from import taxes for machinery and equipment for research centers as well as a waiver for public bidding on contracts focused on innovation for all types of companies, without limitation to those incubated in public research institutions, as suggested in the original text. However, the CNI is against that the SSystem becoming a funding agency for R\&D activities, as mentioned in the bill. The CNI argues that classifying the S-System as a funding agency is not in line with its institutional objectives. The current text, dated from August 6, 2019, has suppressed the mention of the S-System and the bill is still under consideration ${ }^{20}$.

Another example of the weakness of support for institution-intensive solutions in respect of ST\&I efforts can also be seen in the performance of the National Association for R\&D in Innovative Companies (ANPEI21). This Association comprises more than 200 members, including big national and multinational companies, business associations and public and private research institutes $^{22}$. According to the ANPEI, they account for $60 \%$ of total Brazilian R\&D investment, including such innovators as Embraer, IBM, Whirlpool, KimberlyClark, Braskem, Petrobras and others. The Association is actively engaged in the public debate on ST\&I policies and has recently published manifestos defending the maintenance of the Ministry of the ST\&I and the technical autonomy of the National Institute of Intellectual Property ${ }^{23}$.

According to the ANPEI, coordination between industrial policies and innovation law should be a high priority, as should be integration between innovation law and educational policies. These demands along with other priorities are listed in the 'Priority Agenda' that was presented by ANPEI to the Bolsonaro Administration's new Minister of ST\&I. However, beyond these highly visible initiatives, ANPEI is not a relevant actor in lobbying for innovation policies (FRASSÃO, 2018; LIMOEIRO and SCHNEIDER, 2017). A survey of twenty ANPEI members revealed that their lobbying for innovation was less intense than for other economic policy areas, such as trade and tax (FRASSÃO, 2018). The interviewees that had had at least one meeting with government representatives in the last two years were busy trying to solve individual problems, most of them with the Ministries of Trade and Industry ${ }^{24}$ and ST\&I (MCTI); of these, more than $70 \%$ had been partially successful. The study suggests

\footnotetext{
${ }^{20}<$ https://www25.senado.leg.br/web/atividade/materias/-/materia/125998>.

${ }^{21}$ Associação Nacional de Pesquisa e Desenvolvimento das Empresas Inovadoras, ANPEI.

${ }^{22}<$ http://anpei.org.br/associe-se/\#sobre>.

${ }^{23}$ Instituto Nacional de Propriedade Industrial, INPI.

${ }^{24}$ Ministério da Indústria, Comércio Exterior e Serviços, MDIC.
} 
that lobbying for ST\&I policies tends to reproduce the problems of coordination observed in the policy sphere: demands are fragmented and not linked to sectoral interests. Moreover, such lobbying is not used to change existing policies or create new ones, but to make incremental adjustments to benefit specific sectors.

Figure 05. GERD and its share by funding source, Brazil, 2000-2017

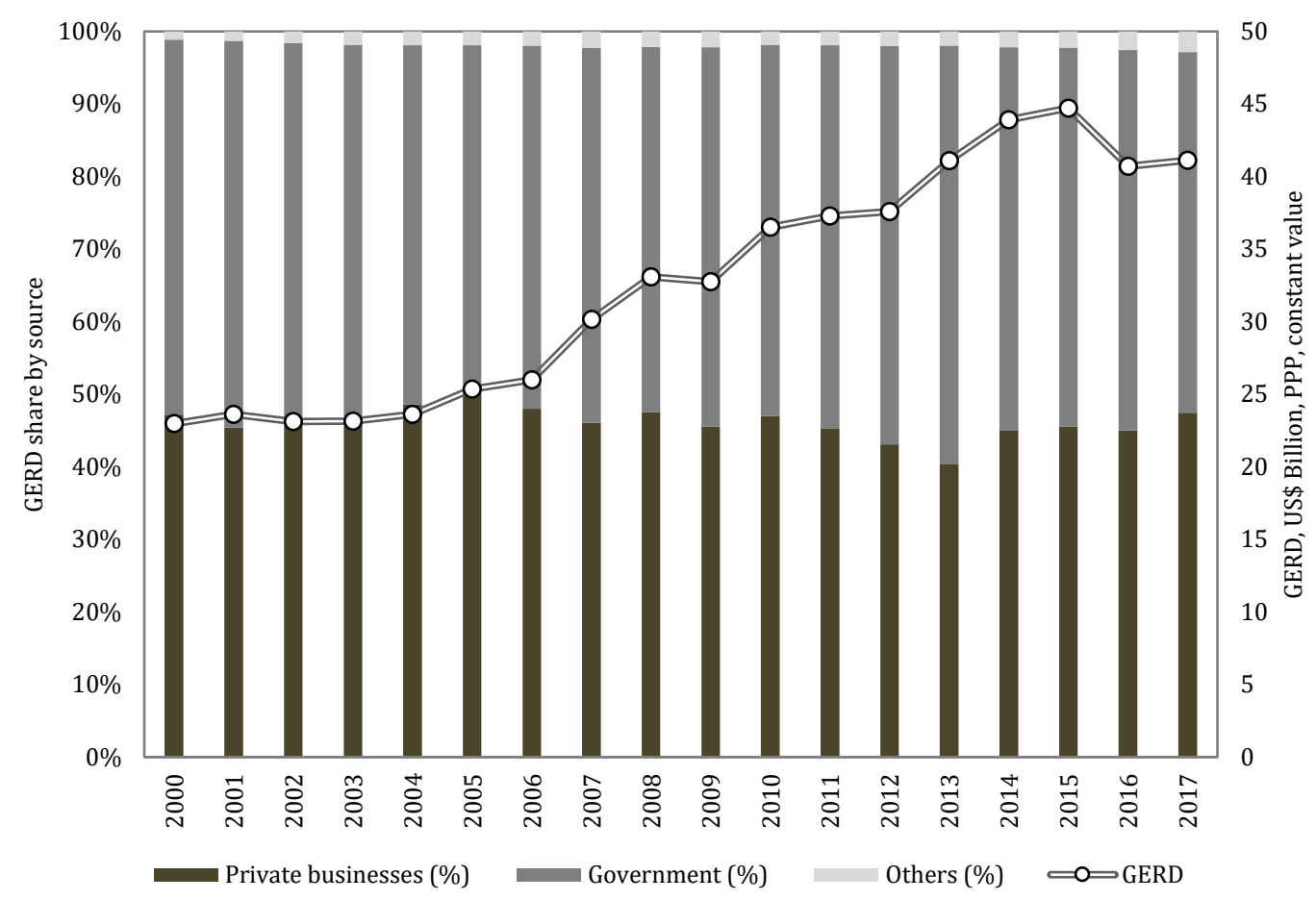

Source: The authors' own. Data sourced from the OECD and compiled by the Brazilian Ministry of Science, Technology, Innovations and Communications (MCTIC).

Note: The current USD figure was deflated by the GDP deflator (year base 2017) available from the World Bank database. 'Others' refer to higher education sector and other non-profit and foreign institutions.

More research is needed on the Brazilian pro-innovation policy lobby. Studies on private lobbying in Brazil reveal that much success is translated into bills that do not go on to become legislation (with more than $50 \%$ being archived or rejected), which suggests that lobbying is more effective at maintaining the status quo than changing it (SANTOS, 2014). Therefore, although a Brazilian upgrading coalition seems to be coming into existence, this coalition has not succeeded in building coordination mechanisms. The Brazilian NSI still strongly depends on the public sphere, and innovative companies have not yet learned how to translate their demands for strengthening the NSI into effective policies. Moreover, other economic issues end up surpassing pro-innovation lobbying in the public debate (macroeconomic stability, labor, pension plans and tax reforms), which gives the government leeway to set its own agenda. 
Table 05. Degree of novelty of main products and processes implemented by innovative businesses, by size, Brazil, 2013, 2014 and 2017

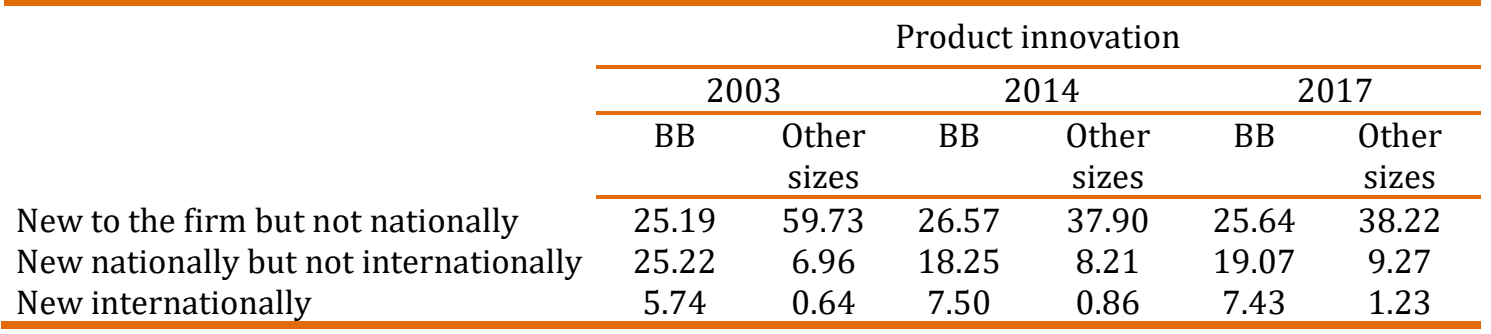

Source: The authors' own. Data sourced from PINTEC/IBGE.

Note: BB (500+ employees); other size businesses (01 - 499 employees).

Brazil's new program for higher education, called the Entrepreneurial and Innovative Institutes and Universities Program ('Future-se') is the latest example of the lack of coordination between public intervention and societal demands. The program was announced by the Minister of Education ${ }^{25}$ on July 17, 2019 and a draft bill was made available for public consultation until August 29, 2019. The Government intended to send the bill to Congress in September 2019. According to the draft, the Program "aims to strengthen administrative autonomy of the Federal Higher Education Institutions - IFES, through a partnership with Federal social organizations and the promotion of self-financing" (MEC, 2019, Art. 01). However, it seems that neither IFES nor the private sector took part in the design of the program, nor were they consulted before the Program was announced 26 .

The main strategy of the 'Future-se' program is the creation of a private fund called the Knowledge Sovereign Fund ${ }^{27}$, whose shares will be traded on the stock exchange to finance research, innovation, entrepreneurship and the internationalization of educational institutions. The intention of the MEC is to raise about BRL 100 billion, from Federal Government assets, constitutional funds, tax incentives, cultural resources and equity funds. To date, no study or official document estimating the capacity of the Fund to meet this goal has been published. On the contrary, a report prepared by the Congress shows that the category of 'selffunding' by educational institutions recorded an average of BRL 01 billion per year in the period 2001 to 2017 and accounted for approximately $1.5 \%$ of IFES revenues in 2017. Private donations, for instance, accounted for only $0.01 \%$ in that year (CEDES, 2018).

\footnotetext{
${ }^{25}$ Ministério da Educação, MEC.

${ }^{26}<$ http://www.andifes.org.br/andifes-defende-realizacao-de-seminarios-e-consultas-aespecialistas-quando-o-programa-future-se-chegar-a-camara/>.

${ }^{27}$ Fundo Soberano do Conhecimento.
} 
Table 6. Degree of novelty of main processes implemented by innovative businesses, by size, Brazil, 2003, 2014 and 2017

\begin{tabular}{|c|c|c|c|c|c|c|}
\hline & \multicolumn{6}{|c|}{ Process innovation } \\
\hline & \multicolumn{2}{|c|}{2003} & \multicolumn{2}{|c|}{2014} & \multicolumn{2}{|c|}{2017} \\
\hline & BB & $\begin{array}{l}\text { Other } \\
\text { sizes }\end{array}$ & BB & $\begin{array}{l}\text { Other } \\
\text { sizes }\end{array}$ & BB & $\begin{array}{l}\text { Other } \\
\text { sizes }\end{array}$ \\
\hline New to the firm but not nationally & 29.29 & 48.00 & 31.34 & 34.58 & 31.04 & 32.34 \\
\hline $\begin{array}{l}\text { New nationally but not } \\
\text { internationally }\end{array}$ & 20.20 & 1.50 & 12.53 & 3.62 & 12.51 & 3.99 \\
\hline New internationally & 2.89 & 0.32 & 3.65 & 0.51 & 4.22 & 0.31 \\
\hline
\end{tabular}

Source: The authors' own. Data sourced from PINTEC/IBGE.

Note: big businesses (500+ employees); other size businesses (01-499 employees).

Considering these figures, the real challenge is to understand how the Ministry of Education can create incentives for private investment in public educational institutions overnight. In a video posted in the website of the Ministry of Education, the Executive Secretary for Higher Education explained that the Program was inspired by soccer games.

So what's the idea [of the Future-se Program]? For example, in soccer: when Neymar goes from Barcelona [football club] to Santos [football club], Barcelona pays a percentage of those funds to Santos. After Neymar leaves Santos for Paris Saint-Germain [football club], a percentage goes back to Santos. So, this is what we call a "future return percentage": it's a kind of royalty because universities create an environment conducive to innovation. So we will tell the investor this: "Investor, why are you going to invest in Neymar? Let's invest in the junior team of Santos [Football Club]". But we don't have the Santos' junior team, we have the Brazilian junior team! We have a network of Federal Universities and Institutes which is gigantic, where many Neymars can emerge, and from there, this return goes back to the very lowest fund, creating a virtuous circle. This increasingly raises the wealth of this Sovereign Fund and then the Universities will be totally independent from their federal budgets. Harvard did it. We are taking inspiration from best practice. Is there a Sovereign Fund like this anywhere else in the world? No. We have put together the various positive actions that there are around the world, we have brought them all together and that's our advantage (LIMA, 2019; time 35m54s).

This clearly shows that the current Government has not understood the real challenges affecting the Brazilian NSI. 'Future-se' reinforces not only the mismatch between universities and firms, but also the enduring lack of coordination between government proposals and the willingness of the private sector in Brazil to expand investment in ST\&I. 
Table 07. Obstacles perceived by non-innovative Brazilian BBs as being highly important, 2003, 2014 and 2017

Obstacles

High innovation costs

Excessive economic risks

Shortage of appropriate funding sources

Weak consumer response to new products

Lack of adequate external technical services

Lack of qualified individuals

Organizational rigidities

Few opportunities to cooperate with other firms/universities

Lack of information about technology

Lack of information about the market

Difficulty conforming to standards, norms and regulations

Source: The authors' own. Data sourced from PINTEC/IBGE.

Note: big businesses (500+ employees); other size businesses (01-499 employees).

\begin{tabular}{cccccc}
\multicolumn{2}{c}{$\begin{array}{c}\text { Non-innovative BBs } \\
(\%)\end{array}$} & \multicolumn{3}{c}{$\begin{array}{c}\text { Other non-innovative businesses } \\
(\%)\end{array}$} \\
\hline 2003 & 2014 & 2017 & 2003 & 2014 & 2017 \\
\hline 43.69 & 57.81 & 54.01 & 71.17 & 58.50 & 59.90 \\
37.75 & 61.48 & 55.12 & 58.48 & 50.29 & 59.47 \\
34.77 & 40.39 & 44.56 & 45.73 & 41.87 & 42.30 \\
7.41 & 7.17 & 11.34 & 7.89 & 18.27 & 13.44 \\
0.00 & 4.44 & 6.10 & 8.13 & 19.24 & 17.37 \\
3.47 & 13.40 & 8.73 & 18.73 & 30.69 & 26.55 \\
5.27 & 5.15 & 7.71 & 6.41 & 21.92 & 15.59 \\
3.47 & 7.89 & 10.74 & 11.89 & 20.23 & 21.60 \\
3.47 & 3.17 & 3.96 & 8.88 & 17.01 & 13.58 \\
0.00 & 2.04 & 5.18 & 8.05 & 12.52 & 12.98 \\
1.74 & 6.31 & 13.16 & 15.63 & 22.93 & 26.53 \\
\hline
\end{tabular}




\section{Final comments}

We have addressed some institutional and political dynamics involving Brazilian BBs and the State. Our point of departure was the following question: how are the innovative practices and political behavior adopted by BBs able to shape the Brazilian NSI? The assumption behind our question was that the way in which businesses are organized in each country is necessary to understand the political obstacles to its economic upgrading.

Brazil offers an intriguing scenario in which to examine the interactions between BBs and the State in the consolidation of the NSI. On the one hand, the country has developed an active private sector, with domestic BBs and MNCs operating in the most important economic sectors. On the other, the Government has increased its participation in innovation efforts, especially during the 2000s. However, the private share of the GDP in R\&D has not increased, and the rate of innovation of BBs has decreased.

Our claim is that there are mismatches within the public sector (exacerbated by the lack of coordination between actors and instruments within the public sector itself and by the instability of the ST\&I agenda) and there are also mismatches within private sector. We believe that both the Brazilian government and businesses are fragmented and failed to form a strong coalition with a strong interest in fostering innovation as a matter of State with a long-term perspective. As a result, Brazil faces a low-innovation trap, by which we mean a situation in which the interactions between the most important actors responsible for carry out innovation do not enhance the institutions necessary to foster innovation in the rest of the economy. The reasoning behind this argument lies in the way in which BBs are organized in Brazil, which seems to stymie the formation of political coalitions that could push for policies to strengthen the NSI.

In line with our argument, the ongoing lack of coordination of the main institutions of the Brazilian NSI may be a sign that the big players in the system do not care about building institutions that could provide public goods - otherwise, they would be the first ones to raise their voices against the retreat of the State from the front. This suggests that the efforts of the State to stimulate innovation have not created the right incentives for enticing BBs into supporting the NSI. Those that do not depend on public instruments to innovate, 
such as MNCs and some domestic BBs, benefit from the existing resources, such as public funding, human capital and cooperation networks, without contributing to their provision. In this sense, by providing goods unconditionally, the Brazilian State becomes at the same time responsible for and a victim of the low-innovation trap. This situation is reinforced in a negative cycle especially when there is an economic downturn like the one Brazil has been suffering since 2013, which has caused companies to reduce their innovative efforts.

Rather than suggesting actions to escape from the trap, our intention is a distinctly modest one: to call attention to the fact that the strategies and practices adopted by BBs in Brazil are creating a trap for the NSI. Much of the debate on policy prescriptions and institution building in the NSI will be fruitless if the structural and political foundations that block upgrading changes are not fully understood.

Moving this agenda forwards implies a change of focus from institutional arrangements to institutional origins, i.e., recognition that BBs have their own interests that may not be congruent with the upgrading of institutions. The exit from the trap may be found in developing new patterns of interaction among domestic businesses, MNCs and the State. This essay was our first attempt in that direction.

Revised by Fraser Robinson

Submitted on April 05, 2019

Accepted on February 02, 2020

\section{References}

ACEMOGLU, Daron (2008), Oligarchic versus democratic societies. Journal of the European Economic Association. Vol. 06,. № 01, pp. 01-44.

ACEMOGLU, Daron; JOHNSON, Simon, and ROBINSON, James A. (2005), Institutions as a fundamental cause of long-run growth. In: Handbook of economic growth (Vol. 01, Part A). Edited by AGHION, Philippe and DURLAUF, Steven N.. Amsterdam: North Holland. pp. 385-472.

ALBUQUERQUE, Eduardo Motta (2005), Inadequacy of technology and innovation systems at the periphery: notes on Celso Furtado's contributions for a dialogue between evolutionists and struturalists. Paper. Belo Horizonte: UFMG/Cedeplar.

ALBUQUERQUE, Eduardo Motta (1999), National systems of innovation and nonOECD countries: notes about a rudimentary and tentative 'typology'. Brazilian Journal of Political Economy. Vol. 19, № 04, pp. 35-52. 
ALBUQUERQUE, Eduardo Motta; SUZIGAN, Wilson; KRUSS, Glenda, and LEE, Keun (eds) (2015), Innovation, developing national systems of South: University-industry interactions in the global. Available at <https://www.idrc.ca/en/book/developing-national-systems-innovationuniversity-industry-interactions-global-south>. Accessed on April, 22, 2020.

ALDRIGHI, Dante M. and POSTALI, Fernando A. S. (2010), Business groups in Brazil. In: The Oxford handbook of business groups. Edited by COLPAN, Asli M.; HIKINO, Takashi, and LINCOLN, James R.. Oxford: Oxford University Press. pp. 353386.

AMSDEN, Alice H. (2001), The rise of 'the rest': challenges to the West from lateindustrializing economies. New York: Oxford University Press. 405 pp..

AMSDEN, Alice H. (1989), Asia's next giant: South Korea and late industrialization. New York: Oxford University Press. 379 pp..

ARCHIBUGI, Daniele and PIETROBELLI, Carlo (2003), The globalisation of technology and its implications for developing countries: windows of opportunity or further burden? Technological Forecasting and Social Change. Vol. 70, № 09, pp. 861-883.

AROCENA, Rodrigo; GÖRANSSON, Bo and SUTZ, Judith (2015), Knowledge policies and Universities in developing countries: inclusive development and the 'developmental University'. Technology in Society. Vol. 41, pp. 10-20.

AROCENA, Rodrigo and SUTZ, Judith (2010), Looking at national systems of innovation from the South. Industry and Innovation. Vol. 07, № 01, pp. 55-75.

AROCENA, Rodrigo and SUTZ, Judith (2005), Latin American Universities: from an original revolution to an uncertain transition. Higher Education. Vol. 50, pp. 573592.

BASTOS, Valéria Delgado (2012), 2000-2010: uma década de apoio federal à inovação no Brasil. Revista do BNDES. Vol. 37, pp. 127-176.

BREZNITZ, Dan and ORNSTON, Darius (2017), EU financing and innovation in Poland. European Bank for Reconstruction and Development Working Paper $\mathrm{n}$ o 198.

BROWN, Drusilla K.; DEARDORFF, Alan V., and STERN, Robert M. (2003), The effects of multinational production on wages and working conditions in developing countries. Paper.

CARVALHO, Laura (2018), Valsa brasileira: do boom ao caos econômico. São Paulo: Editora Todavia. $192 \mathrm{pp}$. 
CEDES (2018), Financiamento da educação superior no Brasil: impasses e

perspectivas. Brasília: Centro de Estudos e Debates Estratégicos da Câmara dos Deputados. 186 pp..

CHAMINADE, Cristina and EDQUIST, Charles (2010), Rationales for public policy intervention in the innovation process: systems of innovation approach. In: Innovation policy - theory and practice: an international handbook. Edited by SMITS, Rudd E.; KUHLMANN, Stefan, and SHAPIRA, Philip. Cheltenham: Edward Elgar. pp. 95-114.

CHANDLER JR., Alfred D. (1990), Scale and scope: the dynamics of industrial capitalism. Cambridge: Belknap Press. 780 pp..

CHANG, Ha-Joon (ed)(2007), Understanding the relationship between institutions and economic development - some key theoretical issues. In: Institutional change and economic development. New York: United Nations University Press. pp. 17-34.

CHANG, Ha-Joon (ed)(2003), Trade and industrial policy issues. In: Rethinking development economics. London: Anthem Press. pp. 257-276.

CHIARINI, Tulio (2017), U.S. R\&D captive offshoring in Brazil, China and India, 1997-2014. Rome: Istituto di Ricerche sulla Popolazione e le Politiche Sociali (IRPPS), Consiglio Nazionale delle Ricerche (CNR).Working paper.

CHIARINI, Tulio; CALIARI, Thiago; BITTENCOURT, Pablo Felipe, and RAPINI, Marcia Siqueira (2020), U.S. R\&D internationalization in less-developed countries: determinants and insights from Brazil, China, and India. Review of Development Economics. Vol. 24, № 01, pp. 288-315.

CNI (2019), Agenda da mobilização empresarial pela inovação 2019 2020. Brasília: Confederação Nacional da Indústria. Available at <http://www.portaldaindustria.com.br/publicacoes/2018/12/agenda-damei-2019-2020/>. Accessed on April, 22, 2020.

COHEN, Wesley M. (2010), Fifty years of empirical studies of innovative activity and performance. In: Handbook of the economics of innovation. Edited by ROSENBERG, Nathan and HALL, Bronwin H.. Amsterdam: Elsevier. pp. 129-213.

COHEN, Wesley M. and KLEPPER, Steven (1996), A reprise of size and R\&D. The Economics Journal. Vol. 106, № 437, pp. 925-951.

CRESPI, Gustavo; TACSIR, Ezequiel, and VARGAS, Fernando (2016), Innovation dynamics and productivity: evidence for Latin America. In: Firm innovation and productivity in Latin America and the Caribbean: the engine of economic development. Edited by GRAZZI, Matteo and PIETROBELLI, Carlo. Washington: Palgrave MacMillan. pp. 37-72. 
CRESPI, Gustavo and ZUÑIGA, Pluvia (2012), Innovation and productivity: evidence from six Latin American countries. World Development. Vol. 40, № 02, pp. 273-290.

DAHLMAN, Carl J. and FRISCHTAK, Claudio R. (1990), National systems supporting technical advance in industry: the Brazilian experience. Washington: The World Bank, Industry and Energy Department. Working Paper.

DONER, Richard F. and SCHNEIDER, Ben Ross (2019), Technical education in the middle income trap: building coalitions for skill formation. The Journal of Development Studies. Vol. 56, № 04, pp. 680-697.

DONER, Richard F. and SCHNEIDER, Ben Ross (2016), The middle-income trap: more politics than economics. World Politics. Vol. 68, № 04, pp. 608-644.

DOSI, Giovanni; FREEMAN, Christopher; NELSON, Richard, and SOETE, Luc (eds) (1988), Technical change and economic theory. London: Pinter Publishers. 646 pp..

DUTRÉNIT, Gabriela and ARZA, Valeria (2015), Features of interactions between public research organizations and industry in Latin America: the perspective of researchers and firms. In: Developing national systems of innovation: Universityindustry interaction in the global South. Edited by ALBUQUERQUE, Eduardo; SUZIGAN, Wilson; KRUSS, Glenda, and LEE, Keun Cheltenham: Edward Elgar. pp. 93-119.

EDQUIST, Charles (ed) (1997), Systems of innovation: technologies, institutions and organizations. London: Pinter Publishers. 432 pp..

ERBER, Fábio Stefano (2000), Perspectivas da América Latina em Ciência e Tecnologia. Parecerias Estratégicas. Vol. 08, pp.181-200.

EVANS, Peter B. (1995), Embedded autonomy: states and industrial transformation. Princeton: Princeton University Press. 344 pp..

EVANS, Peter B. (1985), Transnational linkages and the economic role of the state: an analysis of developing and industrialized nations in the post-world War II period. In: Bringing the state back. Edited by EVANS, Peter B.; RUESCHEMEYER, Dietrich, and SKOCPOL, Theda. New York: Cambridge University Press. pp. 192226.

EVANS, Peter B. (1980), A tríplice aliança: as multinacionais, as estatais e o capital nacional no desenvolvimento dependente brasileiro. Rio de Janeiro: Zahar. 292 pp..

FAIRFIELD, Tasha (2013), Going where the money is: strategies for taxing economic elites in unequal democracies. World Development. Vol. 47, pp. 01-32. 
FRASSÃO, Caroline Souza (2018), Políticas públicas de inovação. In: Relações governamentais e inovação. Edited by GALVÃO, Eduardo Ribeiro. Brasília: Pensar Relgov. pp. 19-45.

FREEMAN, Chris (1995), The 'national system of innovation' in historical perspective. Cambridge Journal of Economics. Vol. 19, № 01, pp. 05-24.

FREEMAN, Chris (1987), Technology policy and economic performance: lessons from Japan. London: Pinter Publishers. 155 pp..

FURTADO, Celso (1987), Underdevelopment: to conform or to reform. In: Pioneers in development: second series. Edited by MEIER, Gerald M. and SEERS, Dudley. London: Oxford University Press. pp. 211-227.

FURTADO, Celso (1959), Formação econômica do Brasil. Rio de Janeiro: Fundo de Cultura. 291 pp..

GERSCHENKRON, Alexander (1962), Economic backwardness in historical perspective: a book of essays. Cambridge: Belknap Press. 456 pp..

GOUREVITCH, Peter (1986), Politics in hard times: comparative responses to international economic crises. London: Cornell University Press. 272 pp..

GUELLEC, Dominique and POTTERIE, Bruno Van Pottelsberghe De La (2003), The impact of public R\&D expenditure on business R\&D. Economics of Innovation and New Technology. Vol. 12, № 03, pp. 225-243.

HEYES, Jason and RAINBIRD, Helen (2011), The state, business, and training. In: The Oxford handbook of business and government. Edited by COEN, David; GRANT, Wyn, and WILSON, Graham. New York: Oxford University Press. pp. 544-564.

HIRATUKA, Célio; COUTINHO, Luciano, and LAPLANE, Mariano (eds)(2003), Internacionalização e desenvolvimento da indústria no Brasil. São Paulo: Editora UNESP. 352 pp..

HOU, Chi-Ming, and GEE, San (1993), National systems supporting technical advance in industry: the case of Taiwan. In: National innovation systems: a comparative analysis. Edited by NELSON, Richard R.. New York: Oxford University Press. pp. 384-413.

KATZ, Jorge (2000), Pasado y presente del comportamiento tecnológico de América Latina. Santiago: CEPAL/ONU. 80 pp..

KIM, Linsu (1999), Building technological capability for industrialization: analytical frameworks and Korea's experience. Industrial and Corporate Change. Vol. 08, № 01, pp. 111-136. 
KOHLI, Atul (2009), Nationalist versus dependent capitalist development: alternate pathways of Asia and Latin America in a globalized world. Studies in Comparative International Development. Vol. 44, № 04, pp. 386-410.

LAURENS, Patricia; BAS, Christian Le; SCHOEN, Antoine; VILLARD, Lionel, and LARÉDO, Philippe (2015), The rate and motives of the internationalisation of large firm R\&D(1994-2005). Research Policy. Vol. 44, № 03, pp. 765-776.

LAZZARINI, Sergio G. (2018), Capitalismo de laços: os donos do Brasil e suas conexões. São Paulo: Bei Editora. 296 pp..

LEE, Kinsu (2019), The art of economic catch-up: barriers, detours and leapfrogging in innovation system. Cambridge: Cambridge University Press. 300 pp..

LIMA, Arnaldo (2019), Lançamento do Programa "Future-se" pelo Ministério da Educação. Brasília. 51:21m. Available at $<$ http://portal.mec.gov.br/index.php?option=com_content\&view=article\&id= 78211:mec-lanca-programa-para-aumentar-a-autonomia-financeira-deuniversidades-e-institutos\&catid=212\&Itemid=86>. Accessed on April, 22, 2020.

LIMOEIRO, Danilo and SCHNEIDER, Ben Ross (2017), State-led innovation: SOEs, institutional fragmentation, and policy making in Brazil. Cambridge: MIT Industrial Performance Center Working Paper Series.

LUNDVALL, Bengt-Åke (2007), National innovation systems: analytical concept and development tool. Industry and Innovation. Vol. 14, № 01, pp. 95-119.

LUNDVALL, Bengt-Åke (ed) (1992), National innovation systems: towards a theory of innovation and interactive learning. London: Pinter Publishers. $342 \mathrm{pp}$..

MAZZUCATO, Mariana (2019), The value of everything: making and taking in the global economy. London: Penguin Random House. 384 pp..

MAZZUCATO, Mariana (2013), The entrepreneurial state: debunking ppblic vs. private sector myths. New York: Anthem Press. 266 pp..

MAZZUCATO, Mariana and PENNA, Caetano (2016), The Brazilian innovation system: a mission-oriented policy proposal. Brasilia: Centro de Gestão e Estudos Estratégicos (CGEE). 119 pp..

MONTALBANO, Pierluigi; NENCI, Silvia, and PIETROBELLI, Carlo (2016), International linkages, value-added trade, and firm productivity in Latin America and the Caribbean. In: Firm innovation and productivity in Latin America and the Caribbean: the engine of economic development. Edited by GRAZZI, Matteo and PIETROBELLI, Carlo. Washington: Palgrave MacMillan. pp. 285-316. 
NASSIF, André; BRESSER-PEREIRA, Luiz Carlos, and FEIJO, Carmem (2018), The case for reindustrialisation in developing countries: towards the connection between the macroeconomic regime and the industrial policy in Brazil. Cambridge Journal of Economics. Vol. 42, № 02, pp. 355-381.

NSB (2016), Science \& engineering indicators 2016. Arlington: National Science Board (NSB), National Science Foundation (NSF). 893 pp..

NEGRI, Fernanda and RAUEN, Andre Tortato (2018), Innovation and policies in Brazil during the 2000s: the need for new paths. Brasilia: IPEA. Paper.

NELSON, Richard R. (2008), Economic development from the perspective of evolutionary economic theory. Oxford Development Studies. Vol. 36, № 01, pp. 0921.

NELSON, Richard R. and WINTER, Sidney G. (1982), An evolutionary theory of economic change. Cambridge: The Belknap Press of Harvard University Press. 454 pp..

ODAGIRI, Hiroyuki (2006), Advanced of science-based industries and the changing innovation system of Japan. In: Asia's innovation systems in transition. Edited by LUNDVALL, Bengt-Åke; INTARAKUMNERD, Patarapong, and VANG, Jan. Cheltenham: Edward Elgar Publishing. pp. 200-226.

OECD (2018), Latin American economic outlook 2018: rethinking institutions for development. Paris: Organisation for Economic Co-operation and Development. 253 pp..

PACHECO, Carlos Américo (2019) Institutional dimentions of innovation policy in Brazil. In: Innovation in Brazil: advancing development in the 21st Century. Edited by REYNOLDS, Elisabeth B.; SCHNEIDER, Ben Ross, and ZYLBERBERG, Ezequiel. New York: Routledge. pp. 171-188.

PAGÉS, Carmen (ed)(2010), The importance of ideas: innovation and productivity in Latin America. In: The age of productivity transforming economies from the bottom up. Washington: Palgrave MacMillan. pp. 223-255.

PELAEZ, Victor; INVERNIZZi, Noela; FUCK, Marcos Paulo; BAGATOLLI, Carolina, and OLIVEIRA, Moacir Rodrigues (2017), The volatility of S\&T policy agenda in Brazil. Brazilian Journal of Public Administration.Vol. 51, № 05, pp. 788-809.

PENROSE, Edith (1959), The theory of the growth of the firm. Oxford: Oxford University Press. 304 pp..

PEREIRA, Newton Müller (2005), Fundos setoriais: avaliação das estratégias de implementação e gestão. Brasilia: IPEA. Paper. 
PÉREZ, Carlota (2001), Technological change and opportunities for development as a moving target. Cepal Review. Vol. 75, pp. 109-130.

PRZEWORSKI, Adam (2007), Political rights, property rights, and economic development. New York: Department of Politics, New York University. Paper.

RAFFO, Julio Diego; LHUILLERY, Stéphane, and MIOTTI, Egidio Luis (2008), Northern and Southern innovativity: a comparison across European and Latin American countries. The European Journal of Development Research. Vol. 20, № 02, pp. 219-239.

ROSSI, Pedro and DWECK, Esther (2016), Impacts of the new fiscal regime on health and education. Cadernos de Saúde Pública. Vol. 32, № 12, pp. 01-05.

SÁ, Creso (2005), Research policy in emergin economies: Brazil's sector funds. Minerva. Vol. 43, pp. 245-263.

SANTOS, Manoel Leonardo (2014), Representação de interesses na Câmara dos Deputados: o lobby e o sucesso da agenda legislativa da indústria. Revista IberoAmericana de Estudos Legislativos. Vol. 01, pp. 52-70.

SCHNEIDER, Ben Ross (2010), Business groups and the state: the politics of expansion, restructuring and collapse. In: The Oxford handbook of business groups. Edited by COLPAN, Asli M.; HIKINO, Takashi, and LINCOLN, James R.. Oxford: Oxford University Press. pp.. 650-669.

SCHUMACHER, Ernst Friedrich (1973), Small is beautiful: a study of economics as if people mattered. London: Harper Collins. 288 pp..

SCHUMPETER, Joseph A. (2017), The theory of economic development. New York: Routledge. 320 pp..

SCHUMPETER, Joseph A. (2003), Capitalism, socialism and democracy. New York: Routledge. 431 pp..

SRINIVAS, Smita and SUTZ, Judith (2008), Developing countries and innovation: searching for a new analytical approach. Technology in Society. Vol. 30, pp. 129140.

STEIN, Guilherme de Queiroz and HERRLEIN-JR., Ronaldo (2016), Política industrial no Brasil: uma análise das estratégias propostas na experiência recente (2003-2014). Planejamento e Políticas Públicas. Vol. 47, pp. 251-287.

SUZIGAN, Wilson and ALBUQUERQUE, Eduardo Motta (2011), The underestimated role of Universities for the Brazilian system of innovation. Brazilian Journal of Political Economy. Vol. 31, № 01, pp. 03-30. 
SUZIGAN, Wilson and FURTADO, João (2010), Instituições e políticas industriais e tecnológicas: reflexões a partir da experiência brasileira. Estudos Econômicos. Vol. 40, № 01, pp. 07-41.

SUZIGAN, Wilson; GARCIA, Renato, and FEITOSA, Paulo (2020), Institutions and industrial policy in Brazil after two decades: have we built the needed institutions? Economics of Innovation and New Technology. Paper.

SZAPIRO, Marina; VARGAS, Marco Antônio, and CASSIOLATO, José Eduardo (2016), Advances and limitations of the Brazilian innovation policy over the past decade: an exploratory analysis. Espacios. Vol. 37, № 05, pp. 01-13.

TCU - TRIBUNAL DE CONTAS DA UNIÃO (2018), TCU detecta ausência de estrutura de coordenação das políticas federais de fomento à inovação. TC 017.220/2018-1. Available at <https://portal.tcu.gov.br/imprensa/noticias/tcu-detecta-ausencia-deestrutura-de-coordenacao-das-politicas-federais-de-fomento-a-inovacao.htm>. Accessed on April, 22, 2020.

TONI, Jackson de (2007), Novos arranjos institucionais na renovação da política industrial brasileira. Ensaios FEE. Vol. 28, № 01, pp. 127-158.

TURCHI, Lenita Maria and MORAIS, José Mauro de (eds)(2017), Políticas de apoio à inovação tecnológica no Brasil: avanços recentes, limitações e propostas de ações. Brasília: IPEA. 485 pp..

WESTPHAL, Larry E.; KIM, Linsu, and DAHLMAN, Carl (1985), Reflections on the Republic of Korea's acquistion of technological capability. In: International technology transfer: concepts, measures, and comparisons. Edited by ROSENBERG, Nathan and FRISCHTAK, Claudio. New York: Praeger Publishers. pp. 167-221.

YEUNG, Henry Wai-chung (2006), Innovating for global competition: Singapore's pathway to high-tech development. In: Asia's innovation systems in transition. Edited by LUNDVALL, Bengt-Åke; INTARAKUMNERD, Patarapong, and VANG, Jan. Cheltenham: Edward Elgar Publishing. pp. 257-292.

ZACHAREWICZ, Thomas; SANZ-MENÉNDEZ, Luis, and JONKERS, Koen (2017), The internationalisation of research and technology organisations. Luxembourg: Publications Office of the European Union. 37 pp..

ZUCOLOTO, Graziela Ferrero and CASSIOLATO, José Eduardo (2013), Desenvolvimento tecnológico por origem de capital: a experiência brasileira recente. Revista Brasileira de Inovação. Vol. 12, № 01, pp. 133-170.

ZUÑIGA, Pluvia; NEGRI, Fernanda de; DUTZ, Mark Andrew; PILAT, Dirk, and RAUEN, André Tortato (2016), Conditions for innovation in Brazil: a review of key issues and policy challenges. Brasília: IPEA. 